NBER WORKING PAPER SERIES

\title{
TAX CHANGES AND ASSET PRICING: TIME-SERIES EVIDENCE
}

\author{
Clemens Sialm
}

Working Paper 11756

http://www.nber.org/papers/w11756

\author{
NATIONAL BUREAU OF ECONOMIC RESEARCH \\ 1050 Massachusetts Avenue \\ Cambridge, MA 02138 \\ November 2005
}

I thank Gene Amromin, Doug Bernheim, Eric Engen, Jim Hines, Marcin Kacperczyk, Ken Klassen, Randall Maringer, Jim Poterba, Steve Sharpe, John Shoven, Joel Slemrod, and seminar participants at the 2003 Tax Symposium at the University of North Carolina, the 2004 American Finance Association Meetings in San Diego, the American Enterprise Institute, Stanford University, and the University of Michigan for helpful comments on earlier drafts. I am grateful to Zhuo Wang for outstanding research assistance. Address: Stephen M. Ross School of Business; University of Michigan; 701 Tappan Street; Ann Arbor, MI 481091234; Phone: (734) 764-3196; Fax: (734) 764-2557; E-mail: sialm@umich.edu. The views expressed herein are those of the author(s) and do not necessarily reflect the views of the National Bureau of Economic Research.

(C2005 by Clemens Sialm. All rights reserved. Short sections of text, not to exceed two paragraphs, may be quoted without explicit permission provided that full credit, including $\odot$ notice, is given to the source. 
Tax Changes and Asset Pricing: Time-Series Evidence

Clemens Sialm

NBER Working Paper No. 11756

November 2005

JEL No. G12, H20, E44

\begin{abstract}
The effective tax rate on equity securities has fluctuated considerably in the U.S. between 19172004. This study investigates whether personal taxes on equity securities are related to stock valuations using the time-series variation in tax burdens. The paper finds an economically and statistically significant relationship between asset valuations and personal tax rates. Consistent with tax capitalization, stock valuations tend to be relatively low when tax burdens are relatively high.

Clemens Sialm

University of Michigan Business School

701 Tappan Street

D3219

Ann Arbor, MI 48109-1234

and NBER

sialm@umich.edu
\end{abstract}




\section{Introduction}

Taxes have an important impact on effective asset returns for taxable investors. If the marginal investor is subject to taxes, then asset valuations and asset returns should reflect this tax burden in equilibrium. In particular, to compensate taxable investors for their tax burden, before-tax asset returns should be higher and asset valuations should be lower in periods of relatively high tax rates. On the other hand, taxes should not affect asset valuations if the marginal investor is effectively tax-exempt, as first discussed by Miller and Scholes (1978). This study tests empirically whether dividend and capital gains taxes are capitalized into asset prices using a new data set covering personal tax burdens on the aggregate U.S. stock market over the period between 1917-2004.

The effect of personal dividend and capital gains taxes on stock prices and stock returns has received a lot of attention in the economics, accounting, and finance literatures. ${ }^{1}$ A first group of papers has analyzed whether asset returns depend on dividend yields, based on the after-tax version of the CAPM by Brennan (1970). ${ }^{2}$ A second group of papers attempts to identify the relationship between tax rates and dividend yields using ex-dividend date price data. ${ }^{3}$ A third group of papers analyzes whether there is a relationship between asset valuations and tax rates. ${ }^{4}$

Despite the extensive literature in this area, the question of whether taxes are capitalized or not has not yet been resolved. Whereas the previous empirical literature on tax capitalization analyzed primarily the cross-section of asset prices and asset

\footnotetext{
${ }^{1}$ See Auerbach (2002), Poterba (2002), and Allen and Michaely (2003) for reviews of this literature.

${ }^{2}$ The papers in this literature include, for example, Black and Scholes (1974), Litzenberger and Ramaswamy (1979), Blume (1980), Gordon and Bradford (1980), Miller and Scholes (1982), Poterba and Summers (1984), and Naranjo, Nimalendran, and Ryngaert (1998).

${ }^{3}$ The papers in this literature include, for example, Elton and Gruber (1970), Eades, Hess, and Kim (1984), Barclay (1987), Michaely (1991), Frank and Jagannathan (1998), Green and Rydqvist (1999), Graham, Michaely, and Roberts (2003), Elton, Gruber, and Blake (2005), and Chetty, Rosenberg, and Saez (2005)

${ }^{4}$ See, for example, Fama and French (1998), Harris, Hubbard, and Kemsley (2001), and Auerbach and Hassett (2005).
} 
returns, my paper sheds light on this tax capitalization controversy by performing a new test based on the substantial time-series variation in effective tax rates on equity securities.

My paper is related to McGrattan and Prescott (2005), who derive the quantitative impact of tax and regulatory changes on equity values using a growth theory model. They show that these regulatory changes can explain the large secular movements in corporate equity values relative to GDP. McGrattan and Prescott (2005) base their inferences on a carefully calibrated growth model. However, they do not perform an econometric analysis of the relationship between tax rates and asset valuations. The test in my paper investigates empirically whether there is a statistically significant relationship between taxes and asset valuations over the longer period between 19172004. Consistent with McGrattan and Prescott (2005), I find a negative relationship between asset valuations and asset prices controlling for many macroeconomic factors.

An influential literature in public economics has investigated the impact of dividend tax changes on economic activity. Under the "traditional" view dividend taxes affect the marginal source of finance, while under the "new" view developed by King (1977), Auerbach (1979), and Bradford (1981) dividend taxes have no impact on the investment incentives of firms using retentions as marginal source of funds. There has been a significant debate concerning the relative importance of these two views: For example, Poterba and Summers (1985) support the traditional view, while Desai and Goolsbee (2004) and Auerbach and Hassett (2005) find more support for the new view. Although my paper does not directly test the implications of the two views, the theoretical model and the empirical results are broadly consistent with the "new view."

The first part of the paper derives asset valuations in a stylized general equilibrium model, based on the exchange economy model of Lucas (1978). My model generalizes the Lucas model by introducing stochastic dividend taxes. The theoretical results 
show that, under plausible conditions, asset valuations tend to be lower in periods where taxes are relatively high. Relatively low asset valuations in high-tax regimes generate relatively high before-tax returns, which compensate investors for the tax burden. The theoretical model in my paper differs from McGrattan and Prescott (2005) by explicitly incorporating the uncertainty of the tax code.

The second part of the paper computes effective tax rates on equity securities following Poterba (1987b) and McGrattan and Prescott (2005). This section demonstrates that the aggregate tax burden of equity securities has varied significantly between 1917-2004. For example, the effective tax rate on equity securities amounted to approximately 40 percent in the early 1950 s and declined to about 5 percent in 2004. These substantial variations in tax rates are caused by three main factors: First, several recent tax reforms gradually reduced the marginal statutory tax rates on investment income. Second, corporations adjusted their distribution behavior and substituted tax-favored share repurchases for highly taxed dividends during the last decades. Third, the introduction of pensions and other tax-qualified savings opportunities reduced the proportion of equities held by taxable investors significantly, resulting in a decrease in the effective tax rate.

The main part of the paper presents a new test of tax capitalization that relates equity valuations, such as the price-earnings ratio of the aggregate stock market, to effective tax rates between 1917-2004. I find a negative relationship between asset valuations and effective tax rates controlling for various macroeconomic factors. The negative relationship is both statistically and economically significant. Consistent with tax capitalization, I also find a positive relationship between taxes and asset returns, indicating that investors are compensated for higher taxes with higher average before-tax returns.

The paper is structured as follows: Section 2 investigates the relationship between dividend taxes and asset valuations in a stylized general equilibrium model. Section 3 
summarizes the major tax reforms between 1913 and 2004 and derives the historical effective tax rates on asset returns over this period. Section 4 reports the main results of this paper, investigating whether there is a systematic relationship between the effective tax rate and equity valuations using the time-series variation in the effective tax rate of the U.S. stock market. This section also includes a large number of robustness tests that confirm the results using various specifications. Section 5 concludes.

\section{Theory}

This section describes a stylized general equilibrium model of asset markets that generalizes the Lucas (1978) model by introducing stochastic dividend taxation. ${ }^{5}$

\subsection{Assumptions}

The output in the exchange economy is exogenous and perishable. Aggregate output $d>0$ follows a geometric random walk with drift, where $z_{t+1}$ denotes its stochastic growth rate. Output growth $z_{t+1}$ has a constant mean of $\mu$ and a standard deviation of $\sigma$. The distribution of the variables is assumed to remain constant over time.

$$
d_{t+1}=d_{t} \exp \left(z_{t+1}\right), \quad z_{t+1} \sim N\left(\mu, \sigma^{2}\right) .
$$

The economy consists of only one security that corresponds to the market portfolio of all assets. It is possible to introduce additional assets that are in zero net supply without affecting the main asset pricing implications. The asset pays the dividend of $d_{t}$ at the beginning of each period $t$. The price of equity $p_{t}$ is defined 'ex-dividend.'

\footnotetext{
${ }^{5}$ The model presented in this section is related to the model in Sialm (2005a), who analyzes the impact of stochastic taxation on equity and term premia. One difference between the two models is that the model in the current paper describes a dividend tax while the model in Sialm (2005a) describes a consumption tax.
} 
Assets can be traded without incurring any transaction costs, and investors face no borrowing or short-selling constraints.

The government taxes the dividends at a flat tax rate $\tau_{t}$. Tax rates are stochastic and follow a two-state Markov-Chain with $0 \leq \tau_{L}<\tau_{H}<1$. The transition probabilities are assumed to be equal in the two states and $\phi$ denotes the probability that the tax rate will not change in the next period:

$$
\phi=\operatorname{Prob}\left(\tau_{t+1}=\tau_{t}\right)
$$

To keep the model tractable, it is necessary to make several simplifying assumptions. First, the model assumes a flat tax on the total distributions of companies and excludes taxes on capital gains. Furthermore, companies are not allowed to adjust their distribution policies by changing their dividend payout ratios. However, the tax rate can be thought of as an effective tax rate that aggregates all the various tax rates and also incorporates the corporate distribution behavior in reduced form. ${ }^{6}$ Second, the model focuses on the impact of personal taxation and does not explicitly take into account corporate taxes, since the dividends paid by the companies are already adjusted for corporate taxes. Thus, a change in the corporation tax would affect the dividend process instead. Third, the growth rate of the economy is assumed to be independent of the tax regime. Numerical computations show that this assumption has no significant impact on the qualitative results for plausible calibrations.

The representative consumer purchases the asset in quantity $x_{t}$ to maximize expected life-time utility. The discount factor is denoted by $\beta \in(0,1)$. The period utility is denoted by $u(c)$, where $u^{\prime}(c)>0$ and $u^{\prime \prime}(c) \leq 0$.

\footnotetext{
${ }^{6}$ For example, if companies reduce their dividend distributions in high-tax regimes and replace the dividends partially with tax-preferred share repurchases, then the effective tax rate would not increase as much as the statutory dividend tax rate. Companies will not completely offset tax changes if there are some benefits of paying dividends.
} 
The consumer's problem is to maximize:

$$
E_{t} \sum_{i=0}^{\infty} \beta^{i} u\left(c_{t+i}\right)
$$

where:

$$
c_{t}=\left(1-\tau_{t}\right) d_{t} x_{t-1}+p_{t}\left(x_{t-1}-x_{t}\right) .
$$

Consumers are assumed to have a power-utility function with a coefficient of relative risk aversion $\alpha \in[0, \infty)$.

$$
u\left(c_{t}\right)=\frac{c_{t}^{1-\alpha}-1}{1-\alpha} .
$$

Individuals with $\alpha=0$ are risk-neutral and individuals with $\alpha=1$ have logarithmic preferences $u\left(c_{t}\right)=\ln \left(c_{t}\right)$. With power utility, the risk aversion coefficient equals the reciprocal of the elasticity of intertemporal substitution.

The first-order condition is:

$$
p_{t}=\beta E_{t}\left[\frac{u^{\prime}\left(c_{t+1}\right)}{u^{\prime}\left(c_{t}\right)}\left(p_{t+1}+\left(1-\tau_{t}\right) d_{t+1}\right)\right] \text {. }
$$

This equation shows that the price of the asset $p_{t}$ is the present discounted value of the future expected after-tax value of the asset $p_{t+1}+\left(1-\tau_{t+1}\right) d_{t+1}$, where the stochastic discount factor is $m_{t+1}=\beta u^{\prime}\left(c_{t+1}\right) / u^{\prime}\left(c_{t}\right)$.

An optimal solution to the agent's maximization problem also must satisfy the following transversality condition:

$$
\lim _{i \rightarrow \infty} \beta^{i} E_{t}\left[u^{\prime}\left(c_{t+i}\right)\left(1-\tau_{t+i}\right) p_{t+1} x_{t+i}\right]=0 .
$$

For market equilibrium, the demand of the asset must equal the exogenous supply. 
In equilibrium, the consumption of the representative agent amounts to:

$$
c_{t}=\left(1-\tau_{t}\right) d_{t}
$$

\subsection{Equity Valuations}

The price-dividend ratio of the asset $\delta_{t}=p_{t} / d_{t}$ can be expressed in equilibrium as follows:

$$
\begin{aligned}
\delta_{t} & =\beta E_{t}\left[\frac{u^{\prime}\left(c_{t+1}\right)}{u^{\prime}\left(c_{t}\right)} \frac{d_{t+1}}{d_{t}}\left(\delta_{t+1}+\left(1-\tau_{t+1}\right)\right)\right] \\
& =\beta E_{t}\left[\left(\frac{1-\tau_{t+1}}{1-\tau_{t}}\right)^{-\alpha}\left(\frac{d_{t+1}}{d_{t}}\right)^{1-\alpha}\left(\delta_{t+1}+\left(1-\tau_{t+1}\right)\right)\right]
\end{aligned}
$$

This valuation equation is time-homogenous and depends only on the current tax regime and is denoted by $\delta_{t}=\delta_{H}$ if $\tau_{t}=\tau_{H}$ and $\delta_{t}=\delta_{L}$ otherwise. The price-dividend ratios of the asset can be solved in closed form, as shown in Appendix A.

This section determines the conditions under which equity valuations are higher in the low-tax regimes.

Proposition 1 The price-dividend ratio is higher (lower) in the low-tax regime if the tax regimes are relatively persistent (transient):

$$
\delta_{L} \gtreqless \delta_{H} \quad \text { if } \quad \phi \gtreqless \tilde{\phi} .
$$

Proof: All proofs can be found in the Appendix.

Proposition 1 indicates that asset valuations are relatively higher in the low-tax regime whenever tax regimes are sufficiently persistent. However, this condition is not very restrictive. As shown in the Appendix, the condition $\phi>\tilde{\phi}$ is always is satisfied if $\phi>0.5$ and tax rates are more likely to remain unchanged than to change. 
Furthermore, this condition also is satisfied if investors are sufficiently risk-averse $(\alpha>0.5)$ for any persistence levels $\phi$.

To illustrate the impact of taxes on asset valuations, I compute numerically pricedividend ratios in the two tax regimes for four different levels of risk-aversion $\alpha$ and at different transition probabilities $\phi$. The numerical example uses the following parameter values: The time preference factor is $\beta=0.95$; the tax rates in the two regimes are $\tau_{L}=0.3$ and $\tau_{H}=0.4$, respectively; the mean dividend growth rate is $\mu=0.02$; and the standard deviation of the dividend growth rate is $\sigma=0.1$. The results do not depend significantly on these assumed parameter values.

Figure 1 depicts the price-dividend ratios at different persistence levels. The first plot depicts the price-dividend ratio if investors are risk-neutral $(\alpha=0)$. In this case, asset valuations are higher in the high-tax regime if $\phi<0.5$. This surprising result occurs because of the strong mean reversion in tax rates with $\phi<0.5$, since tax rates are in this case more likely to be low next period if they are currently high. If $\phi=0.5$, then the price-dividend ratio is identical in the two tax regimes, because taxes are equally likely to be high or low next period regardless of the current tax level. Overall, valuation levels in the low-tax regime increase with the persistence level $\phi$, because higher persistence levels indicate that it is more likely that tax rates also will be low in the next period. This first effect is called the "cash-flow effect," because taxes reduce the cash flows investors obtain from their investments.

If investors are risk-averse, then asset prices will in addition reflect the desire of investors to smooth their consumption over time. If taxes are temporarily low, then their current consumption is relatively high and they would like to save some of the dividends. In equilibrium, to induce investors to consume the complete after-tax dividend, the expected returns in low-tax regimes need to be lowered to decrease the attractiveness of saving. Thus, asset valuations in the low-tax regime will increase relative to asset valuations in the high-tax regime as risk-aversion increases. The desire 
to smooth consumption becomes less pronounced if tax regimes are more persistent. This second effect is called the "consumption-smoothing effect" and goes in the opposite direction from the "cash-flow effect." For example, if risk-aversion is $\alpha=1$, then the two effects exactly offset each other and the asset valuations in the two regimes do not depend on the persistence level, as shown in the second plot of Figure 1. If investors are more risk-averse than log-utility investors, then the "consumptionsmoothing effect" dominates and the price-earnings ratio in the low-tax regime will decrease with the persistence level.

The price-dividend ratio is higher in the low-tax regime as long as the persistence level is larger than 50 percent or as long as the risk-aversion is sufficiently large.

The next proposition derives asset valuations in the special case, where taxes are permanent $(\phi=1)$ and do not change over time.

Proposition 2 If tax regimes are permanent $(\phi=1)$, then the price-dividend equals:

$$
\delta_{t}=(1-\tau) \frac{\beta \gamma}{1-\beta \gamma}
$$

In this case, the price-dividend ratio is proportional to $1-\tau$ and remains constant over time.

The following proposition investigates whether taxes are fully or just partially capitalized into asset prices:

Proposition 3 If tax regimes are not permanent $(\phi<1)$, then taxes have a more (less) than proportional impact on asset valuations if risk-aversion is relatively high (low):

$$
\frac{\delta_{L}}{\delta_{H}} \lesseqgtr \frac{1-\tau_{L}}{1-\tau_{H}} \quad \text { if } \quad \alpha \lesseqgtr 1
$$

With $\log$-utility $(\alpha=1)$, the ratio between the two prices is just $\delta_{L} / \delta_{H}=(1-$ 
$\left.\tau_{L}\right) /\left(1-\tau_{H}\right)$. In this case, taxes are fully capitalized into asset valuations. The ratio between the two asset valuation levels equals in this case the ratio in an environment with permanent tax rates, as discussed in Proposition 2. This result is surprising since the only relevant tax rate with log-utility is the tax rate in the current tax regime. The tax rate in the other tax regime is irrelevant even if there is a positive probability that this tax rate will eventually affect asset valuations. Proposition 3 also demonstrates that taxes have a more than proportional impact on asset valuations if investors are more risk-averse than log-utility investors.

\subsection{Equity Returns}

Finally, I study the relationship between expected returns and tax rates. The beforetax expected return of the asset is given by:

$$
\lambda_{t}=E\left[\frac{p_{t+1}+d_{t+1}}{p_{t}}\right]=E_{t}\left[\frac{d_{t+1}}{d_{t}} \frac{\delta_{t+1}+1}{\delta_{t}}\right] .
$$

Proposition 4 The expected return is higher (lower) in the high-tax regime if the price-dividend ratio in the high-tax regime is lower (higher) than the price-dividend ratio in the low-tax regime:

$$
\lambda_{H} \gtreqless \lambda_{L} \quad \text { if } \quad \delta_{H} \lesseqgtr \delta_{L} .
$$

Propositions 1 and 4 indicate that asset returns are higher and asset valuations are lower in the high-tax regime as long as tax regimes are sufficiently persistent.

Figure 2 summarizes the corresponding expected returns in the two tax regimes using the parameter values given in Section 2.2. The expected returns in the high-tax regime are always higher than the expected returns in the low-tax regime except when $\delta_{H} \geq \delta_{L}$, which occurs at relatively low persistence levels $\phi \leq \tilde{\phi}$. 
The stylized theoretical model in this section demonstrates that under plausible conditions asset valuations tend to be higher and expected returns tend to be lower during low tax regimes. In Section 4, I will test these two predictions empirically using data on U.S. stock prices. The next section derives the time-series of effective tax rates between 1917-2004.

\section{Effective Tax Rates}

One of the biggest challenges of analyzing the effects of taxes on asset prices is the identity of the marginal taxpayer. Taxes are irrelevant in asset pricing if the marginal taxpayer is tax-exempt. On the other hand, taxes will have an impact on asset prices if the marginal stockholder is an individual in a high tax bracket. This section describes the derivation of the effective tax rates of equity securities over the period between 1917 and 2004. This study follows Poterba (1987b), Poterba (1998), and McGrattan and Prescott (2005) and constructs dollar-weighted average tax rates for the aggregate stock market.

\subsection{Definition of Effective Tax Rate}

The effective tax rate of equity securities depends not only on the statutory tax rates, but also on the distribution properties of equity securities. The tax burden on equity is reduced if the aggregate dividend yield is smaller, if capital gains are deferred and capital losses are accelerated, and if a larger proportion of the assets are held in taxqualified environments (for example, pensions and tax-deferred retirement accounts). The effective tax rate on equity securities at time $t \tau_{t}^{\text {eff }}$ is given by:

$$
\tau_{t}^{e f f}=w_{t}^{d i v} \tau_{t}^{d i v}+w_{t}^{s c g} \tau_{t}^{s c g}+w_{t}^{l c g} \tau_{t}^{l c g}
$$

The effective tax rate depends first on the marginal tax rates on dividends $\tau^{\text {div }}$ 
and short- and long-term capital gains $\tau^{s c g}$ and $\tau^{l c g}$. Whereas realized short-term capital gains are taxed at the ordinary income tax rate, realized long-term capital gains are taxed at the capital gains tax rate, which has generally been lower. I use the average marginal tax rates on dividends and capital gains as the relevant tax rates to compute the effective tax rates.

Second, the composition of the sources of income from equity investments has an important impact on the tax burden of an asset portfolio. The proportion of the returns paid as dividends is denoted by $w^{\text {div }}$, while the proportions of realized short- and long-term capital gains are denoted by $w^{s c g}$ and $w^{l c g} .^{7}$ The deferral of the realization of capital gains is beneficial because the present value of the tax liabilities decreases if the tax payments are postponed. In addition, the taxation of capital gains can be avoided completely due to the "step-up of the cost basis" at the time of death, which eliminates the taxation of all unrealized capital gains. Optimal deferral and avoidance strategies can reduce the effective tax rates significantly. ${ }^{8}$

Third, the ability to invest through pension accounts and other tax-qualified savings vehicles reduces the effective tax rate of stocks. The tax rates on dividends and capital gains decrease if a larger fraction of the assets are held by tax-exempt investors or in tax-qualified locations. A more detailed description of the construction of the effective tax rates is given in the Appendix.

\subsection{Statutory Tax Rates}

Marginal statutory tax rates on ordinary income at the federal level have fluctuated considerably, as depicted in Figure 3. The figure shows the statutory federal marginal income tax rates for households in five different tax brackets. The four lower tax

\footnotetext{
${ }^{7}$ Note that the proportions of dividends and realized capital gains do not necessarily add to 100 percent, because capital gains can be deferred indefinitely.

${ }^{8}$ Constantinides (1983), Stiglitz (1983), Constantinides (1984), and Dammon and Spatt (1996) describe several investment strategies to minimize the taxes of financial returns. Poterba (1987a), Auerbach, Burman, and Siegel (2000), and Ivkovich, Poterba, and Weisbenner (2005) show that a large part of the investing public does not engage in tax-minimizing portfolio transactions.
} 
brackets correspond to real income levels of 50, 100, 250, and 500 thousand U.S. dollars expressed in 2004 consumer prices. The fifth curve corresponds to the top marginal income tax rate. ${ }^{9}$ The figure shows the impact of numerous tax reforms since federal taxes were introduced in 1913. The highest marginal income tax rate amounted to 94 percent in 1944 and 1945. Since then marginal income tax rates have declined significantly.

\subsection{Average Marginal Tax Rate}

From Figure 3 it is difficult to determine the actual taxes investors paid, since the tax bracket of the average investor might change over time. The Internal Revenue Service publishes since 1917 the distribution of income sources of different taxpayers in the Statistics of Income. For example, the IRS summarizes annually the total dividends declared by individuals in different income brackets. The marginal tax rate can be determined for each of these income brackets. This information allows the computation of the dollar-weighted marginal tax rate faced by taxable investors on dividend income, as suggested by Poterba (1987b). This tax rate is called the "average marginal tax rate." Such tax rates also will be computed for short- and long-term capital gains. Prior to 1965, I hand-collected tax distribution data from different issues of the Statistics of Income of the IRS to estimate average marginal tax rates. Since 1960 , the NBER computes the average marginal tax rates. ${ }^{10}$

State and local governments impose additional taxes on income from financial assets. The NBER tax series includes state and local taxes. Prior to 1965, I assume that the marginal tax rate from states and localities is a fixed proportion of the federal tax rate according to the current revenues of states and local governments relative

\footnotetext{
${ }^{9}$ The figure lists the tax rates of households with relatively high income levels since a large portion of financial assets is held by individuals in relatively high income tax brackets. Poterba (2000) shows that the top one percent of equity holders account for 53.2 percent of household holdings of corporate stock according to the 1998 Survey of Consumer Finances.

${ }^{10}$ The data can be obtained from http://www.nber.org/ taxsim/dtdy/. Additional information on their model can be found in Feenberg and Coutts (1993).
} 
to the federal government. The Appendix explains the construction of the different time series in more detail.

Figure 4 depicts the average marginal tax rates of dividend income and long-term capital gains between 1917 and 2004. Average dividend tax rates increased from approximately 10 percent in 1925 to more than 50 percent in 1943. The dividend tax rates remained relatively high until Reagan's tax cuts in the 1980s. The Jobs and Growth Tax Reconciliation Act of 2003 capped the maximum federal tax on dividends and long-term capital gains at 15 percent and reduced the average marginal tax rate on dividends substantially. In 2004, the estimated average marginal tax rate on dividends equals 18.7 percent. This exceeds the maximum federal tax rate on qualified dividends primarily because of the additional state and local government taxes on dividends.

The average marginal tax rate on realized long-term capital gains is generally less than the average marginal dividend tax. The Tax Reform Act of 1986 briefly eliminated the distinction between capital gains and ordinary income. In 1997, the maximum capital gains tax rate was lowered from 28 to 20 percent, which resulted in a relatively significant drop in the average capital gains tax rate. The Jobs and Growth Tax Reconciliation Act of 2003 further reduced the federal marginal tax rate on realized long-term capital gains to 15 percent.

\subsection{Sources of Investment Income}

The sources of investment income for equity securities varied considerably over our sample period, as shown in Figure 5. The figure depicts the dividend and the capital gains yields of U.S. stocks. The dividend yield is defined as the ratio between the

total amount of dividends paid by companies in the Standard \& Poor's Composite Index in a given year divided by the market capitalization of these companies at the beginning of the corresponding years. The capital gains yield is defined as the 
total amount of realized short- and long-term capital gains on publicly traded equity securities in each year divided by the initial market capitalization. The data sources are described in more detail in Appendix B.

Dividend income was an important income source for stockholders during most of the period, and dividends became relatively less important during the last two decades. In the 1980s and 1990s, dividend yields decreased substantially as companies retained a larger proportion of their earnings and as they recognized that share repurchases have tax advantages for taxable shareholders compared to dividend payments. This recent drop in the dividend yield decreased the total tax burden of stock investors, since dividends are taxed at higher rates than capital gains.

As dividend yields decreased, capital gains have become a more important source of income of investors. It is interesting to observe that the annual variation in capital gains realization depends on anticipated tax changes. For example, tax realizations were very substantial in 1986, the year prior to significant increases in the long-term capital gains tax rate enacted as part of the Tax Reform Act of 1986. Shareholders were aware of the tax reforms and accelerated the realization of capital gains under the old tax regime.

The IRS also distinguishes between short- and long-term capital gains realizations. During most years since 1950, realized short-term capital losses exceeded the realized short-term gains as investors avoided realizing short-term capital gains, which are taxed heavily relative to long-term capital gains. Furthermore, the absolute shortterm capital gains tend to be considerably smaller in absolute terms than the absolute long-term capital gains over the sample period.

To eliminate the impact of large changes in capital gains realization, it is assumed that investors have a fixed propensity to realize capital gains and capital losses over the sample period out of the total capital gains. On the other hand, I use the actual dividend yield at the beginning of each year as an estimate of the proportion of divi- 
dends paid during a particular time period. Appendix B.3 describes the computation of the distribution weights in more detail.

\subsection{Tax-Qualified Savings Accounts}

One of the most influential tax reforms has been the introduction of various types of tax-qualified pension and retirement accounts, resulting in a substantial decline in the proportion of stocks held by taxable investors. The proportion of corporate equity held by taxable investors decreased from more than 90 percent in the 1950s to 55 percent in 2004. ${ }^{11}$ This dramatic decline is primarily due to the increased importance of pension funds, tax-deferred retirement accounts, and nonprofit organizations. The proportion of equity held in taxable accounts is estimated using the Flow of Funds published by the Board of Governors of the Federal Reserve Bank. ${ }^{12}$

\subsection{Effective Tax Rates}

The empirical section of this paper relates the effective tax rate to the valuation levels of equity securities. The effective tax rate in equation (11) depends on the dividend yield of equity securities, which is inversely related to the valuation level of equity securities. To avoid any spurious correlation between the valuation measures and the effective tax rates, I also compute an effective tax rate using constant distribution weights.

$$
\tau_{t}^{c o n s t}=\bar{w}^{d i v} \tau_{t}^{d i v}+\bar{w}^{s c g} \tau_{t}^{s c g}+\bar{w}^{l c g} \tau_{t}^{l c g}
$$

This alternative definition of effective tax rates eliminates the impact of the large variation of dividend and capital gains yields by using the averages of the distribution weights of dividends $\left(\bar{w}^{d i v}=\sum_{t} w_{t}^{d i v} / T\right)$, short- $\left(\bar{w}^{s c g}=\sum_{t} w_{t}^{s c g} / T\right)$ and long-term

\footnotetext{
${ }^{11}$ Earlier data on the flows of funds are not available. I assume that the proportion of stocks held by taxable investors between 1917 and 1944 equals the proportion in 1945.

${ }^{12}$ Chaplinsky and Seyhun (1990) examine the aggregate dividend tax savings provided to individuals through tax-exempt and tax-deferred savings opportunities.
} 
$\left(\bar{w}^{l c g}=\sum_{t} w_{t}^{l c g} / T\right)$ capital gains over the whole sample period. Thus, this alternative definition ignores an important determinant of the effective tax rates of equity securities and biases our results against finding an impact of taxes on asset valuations. Thus, this second measure of the effective tax rate only reflects the changes in the average capital gains and dividend tax rates. Most empirical results in Section 4 use this alternative definition of the effective tax rate.

Figure 6 summarizes the effective tax rate of equity securities over the sample between 1917-2004. The more volatile curve corresponds to the definition given in equation (11), whereas the more stable curve corresponds to the definition given in equation (12). About one-quarter of the variation of the effective tax rate with variable distribution weights is caused by changes in the dividend yield over time. The effective tax rate using variable distribution weights decreased significantly since the mid-1950s. The effective tax rate of stocks amounted to more than 40 percent in 1950 and decreased to 5.2 percent in 2004. The next section investigates empirically whether there is a relationship between the effective tax rates and the asset valuation levels.

\section{Taxes and Asset Valuations}

The theoretical model presented in Section 2 indicates that higher tax rates are associated with lower asset valuations and higher asset returns. This section studies the relationship between tax rates and asset valuations using the time-series variation in effective tax rates.

It should be kept in mind that the tax rate of the marginal investor will in general be different from the effective tax rate computed previously. However, the measurement error introduced by the fact that the tax rate of the marginal investor is not observable will make it more difficult to reject the hypothesis that taxes have no 
impact on asset valuations.

An additional caveat is that taxes are determined in an endogenous political process and might therefore depend on the economic environment in general and the stock market performance in particular. It is not possible to conclusively determine the causality of the effects described in this paper. However, the multivariate regressions include additional control variables that should capture the direct impact of these variables on asset valuations.

\subsection{Macroeconomic Data}

This section uses an updated version of the data set in Shiller (1989) covering the period between 1917 and 2004. The data are described in more detail in Appendix B.

Table 1 lists summary statistics for the data used. Panel A summarizes the tax variables. The first row summarizes the moments of the effective tax rate using constant weights, as defined in equation (12). The second row reports the effective tax rate based on the time-varying dividend yields, as defined in equation (11). The next two rows summarize the average marginal tax rates on dividends and long-term capital gains, as depicted in Figure 4. The last three rows summarize statutory federal tax rates on dividends for households in three different income brackets, corresponding to Adjusted Gross Incomes of $\$ 100,000, \$ 250,000$, and the maximum income levels in 2004 U.S. dollars. The tax variables differ in their general levels, but they are generally highly correlated with the exception of the average marginal tax rate on long-term capital gains.

Panel B of Table 1 summarizes macroeconomic variables. The first three variables are proxies of aggregate equity valuations. The price-earnings and the price-dividend ratios are defined as the S\&P index level in January of the following year divided by the earnings and the dividends in the current year. Tobin's $q$ is defined following Blanchard, Rhee, and Summers (1993) as the ratio between the market value of 
equity and debt divided by the replacement cost of capital in the nonfinancial corporate sector. The price-earnings ratio has a mean of 15.46 over the whole period and varies between 5.63 (1917) and 46.18 (2001). The price-earnings ratio is highly correlated with the two alternative valuations measures: The correlation with the price-dividend ratio is 78.9 percent, and the correlation with Tobin's $q$ is 71.7 percent. The Appendix describes the derivation of these macroeconomic variables in more detail. All three valuation measures have a significantly negative correlation with the effective tax rate, consistent with a plausible calibration in the theoretical model from Section 2.

The table summarizes additional macroeconomic variables, such as the nominal return of the $\mathrm{S} \& \mathrm{P} 500$ Index, the inflation rate, the real per capita growth rate, the interest rate, and indicator variables for whether the president is affiliated with the Democratic party and for whether the current year is an NBER recession or war year. There is a strong association between taxes and years of war, since taxes were often increased during war periods to pay for the additional government spending. Furthermore, tax rates also tend to be higher under Democratic administrations. However, I do not find a significant relationship between the tax rate and the output growth rate and the recession indicator variable, indicating that the short-term growth rate of the economy does not appear to be very sensitive to the effective tax rate.

Since the price-earnings ratio is highly persistent, it is important to test whether it follows a unit root. A Dickey-Fuller test for a unit root in the price-earnings ratio (and in the logarithm of the price-earnings ratio) can be rejected at the one percent level. ${ }^{13}$ In the subsequent estimations, I will take into account the high autocorrelation of the dependent variable by computing Newey-West standard errors.

Figure 7 depicts the time-series of the price-earnings, the price-dividend, and

\footnotetext{
${ }^{13}$ The Dickey-Fuller test statistic equals 3.882, which is larger than the 1 percent critical level. Moreover, a regression of the difference in the price-earnings ratio on the lagged value of the priceearnings ratio has a coefficient of -0.291 with a standard error of 0.075 . Thus, the process of the price-earnings ratio is significantly different from a unit root.
} 
Tobin's $q$ ratio over the period between 1917 and 2004. The valuation levels vary considerably through time. We observe that asset valuations were relatively low in the early 1950s and in the late 1970s, time periods where taxes were relatively high. On the other hand, asset valuations were relatively high in the 1960s and the 1990s, when effective taxes were relatively low.

To investigate in more detail the relationship between asset valuations and taxes, I summarize in Table 2 the average effective tax rate and the three valuations measures for 15 distinct tax regimes. To determine the relationship between taxes and asset valuations, I compute the Spearman rank correlation, which is simply the Pearson correlation coefficient based on the ranks of the average tax rates and the valuation levels in the different tax regimes. One advantage of the Spearman rank correlation relative to the Pearson correlation coefficient summarized in Table 1 is that the Spearman correlation is not influenced as much by outliers. The results indicate that there is generally a negative correlation between asset valuations and tax regimes. The remainder of this paper will investigate this relationship in more detail using multivariate regressions.

\subsection{Regression Specification}

The correlations in Tables 1 and 2 show a negative relationship between taxes and asset valuations. It is possible that omitted variables affect the tax rates and the asset valuations, thereby causing a bias in the coefficient estimates. This section shows that effective tax rates remain an important determinant of asset valuations even if additional macroeconomic variables are included.

There are many other factors that affect asset valuations besides taxes. The level of interest rates has an important impact on asset valuations, since stocks and fixedincome securities are alternative investment options. As interest rates increase, stock valuations should decline to generate higher expected returns as long as risk premia 
remain unaffected.

A second factor besides the short-term interest rate in determining the discount rate of equity securities is the equity risk premium. The risk premium depends on the risk-aversion of investors and on the anticipated amount of risk during the next time period. Four macroeconomic variables, the inflation rate, the per-capital growth rate in output, an indicator variable for a recession, and an indicator variable for a time period of war, attempt to capture this effect on asset valuations. Uncertainty tends to be larger during periods of high inflation and low growth rates, particularly during wars and recessions. Thus, it should be expected that asset valuations are lower with high inflation, low growth rates, in recessions, and in times of war. However, such crisis times also might be time periods where earnings or dividends are temporarily low. Thus, if this effect dominates the risk-premium effect, then there should be a positive relationship between asset valuation levels and these macroeconomic variables. ${ }^{14}$

The party of the president is included as an additional explanatory variable, since tax levels tend to be higher during Democratic administrations, as shown in Table 1. An impact of the party of the president on asset pricing has been previously investigated by Santa-Clara and Valkanov (2002), who show that asset returns tend to be higher under Democratic presidents.

Finally, I also include a linear time trend to capture omitted variables that change linearly with time. For example, the risk tolerance might have increased over time justifying higher stock valuations in the last part of our sample. The time trend also can capture some tax effects. McDonald (2004) shows that financial innovations introduced during the last several decades allow investors effectively to avoid the taxation of dividends and capital gains. Thus, increasing valuation ratios also could result from such financial innovations.

\footnotetext{
${ }^{14}$ In the empirical estimation section, I will include several robustness tests to investigate these issues more fully. For example, following Campbell and Shiller (1998), I will compute the moving average of earnings over the previous five and ten years to mitigate the impact of temporary cyclical variations in earnings.
} 
The relationship between asset valuations and effective taxes is estimated using the following regression equation:

$$
\begin{aligned}
p_{t} / e_{t}= & \alpha_{0}+\alpha_{1} \tau_{t}^{\text {const }}+\alpha_{2} r f_{t}+\alpha_{3} \pi_{t}+\alpha_{4} g_{t} \\
& +\alpha_{5} \text { dem }_{t}+\alpha_{6} r e c_{t}+\alpha_{7} \text { war }_{t}+\alpha_{8} t+\epsilon_{t} .
\end{aligned}
$$

The dependent variable in the base case is defined as the ratio between the index value of the Standard and Poor's Composite Index $p_{t}$ at the end of the year divided by the earnings of companies in the underlying index $e_{t}$ during the corresponding year. The independent variables in the base case are measured in the current year: The effective tax rate with constant distribution weights is denoted by $\tau_{t}^{\text {const }}$; the short-term interest rate by $r f_{t}$; the inflation rate by $\pi_{t}$; the real per capita growth rate by $g_{t}$; an indicator variable for a Democratic president by $d e m_{t}$; an indicator variable for an NBER recession by $r e c_{t}$; an indicator variable for a year of war by $w_{a r}$; and a linear time trend by $t .^{15}$ If taxes are capitalized into asset prices, then the tax coefficient $\alpha_{1}$ should be negative.

\subsection{Regression Estimates}

Table 3 summarizes the results of the main specification in this section. The first column reports the regression results for a univariate regression, and the second column includes additional macroeconomic control variables and a linear time trend.

The standard errors are given in parentheses and follow Newey and West (1987), where the autocorrelation structure is estimated using a four-year lag. A four-year lag is chosen because the autocorrelations of the price-earnings ratio up to a lag of

\footnotetext{
${ }^{15}$ The empirical specification does not include the corporate tax rate as an additional explanatory variable. Corporate taxes should not affect asset valuations in steady-state since the earnings are measured after the deduction of the corporation tax. The correlation between the corporate and the personal tax rates is relatively high (0.63), resulting in insignificant coefficients on the tax variables if both variables are included.
} 
four years are statistically significant. The significance levels are abbreviated with asterisks: One, two, and three asterisks denote statistical significance at the 10, 5, and 1 percent level, respectively. ${ }^{16}$

The results on the tax coefficient are both economically and statistically significant. For example, the second column shows in the multi-variate analysis that a one percentage point increase in the effective tax rate reduces the price-earnings ratio by 0.35 , or by about 2.3 percent of the mean price-earnings ratio.

The interest rate and the inflation rate also have an important impact on asset valuations. Asset valuation levels tend to be lower when nominal interest rates are higher and when inflation rates are higher. The other macroeconomic variables are less important. Finally, the regression detects a statistically significant positive time trend.

\subsection{Robustness Tests}

This section tests for the robustness of the previously described results using different measures of stock valuations, different tax rates, and alternative specifications.

The endogeneity of taxes might be one issue of the base-case regression estimation. Whereas the numerator $p$ is measured at the beginning of the following year, the denominator $e$ is measured simultaneously with the explanatory variables. To avoid any issues of reverse causality, Table 4 reports in the second column the regression results, where the dependent variable is measured in the subsequent year. However, neither the economic nor the statistical significance of the tax coefficient is affected using this alternative specification.

\footnotetext{
${ }^{16}$ The Newey-West standard errors are significantly higher than the OLS standard errors. For example, the OLS standard error of the tax variable in the second column of Table 3 would have been only 10.30. However, increasing the number of lags beyond four does not increase the standard errors. For example, the standard errors with eight lags are 11.86, compared to 12.84 in the specification with four lags. Thus, the choice of the lag length corresponds to the most conservative Newey-West standard errors.
} 
The derivation of the effective tax rates requires many specific assumptions. Table 5 analyzes whether the impact of taxes is robust if we use alternative tax rates. The first column repeats the regression results from Table 3. The second column defines the effective tax rate as in equation (11) and allows the distribution weights to vary over time. The coefficient on the tax variable becomes slightly more negative and more statistically significant under this specification. This confirms the expectation that the results in the base case using effective tax rates based on constant distribution weights are more conservative.

The third column uses the average marginal tax rate on dividends. This tax rate ignores the composition of the returns between dividends and capital gains and regresses the valuation ratios on the average dividend tax rate, as summarized in Figure 4. The coefficient estimate decreases because the tax rate of dividends is more variable than the effective tax rate. However, the statistical significance increases in this specification slightly relative to the base case summarized in the first column.

The last three columns use the marginal statutory federal tax rates on dividends for investors with real income levels of $\$ 100,000, \$ 250,000$, and the top tax rate. Under all three cases, there is a negative relationship, which is at least statistically significant at the five percent confidence level. The level of the coefficient estimates differs between the various specifications, which should be expected since the different tax variables have very different standard deviations, as summarized in Table 1.

These results indicate that the results are robust to alternative definitions of the relevant tax rate. These robustness tests are important because the tax rate of the marginal investor cannot be observed. Therefore, it is crucial that the results are not driven by an arbitrary choice of the effective tax rate.

Table 6 analyzes the relationship between the effective tax rate on equity and different valuation measures. The first column repeats the estimates in the base case using the price-earnings ratio as the dependent variable. The second and third 
columns use the ratio of the current S\&P 500 Index value divided by the moving average of the real earnings during the previous five and ten years, respectively. By averaging earnings over several years it is possible to partially isolate variations in the stock valuations from short-term variations in earnings due to the business cycle, as discussed by Campbell and Shiller (1998). The fourth column uses the price-dividend ratio as the dependent variable, and the fifth column uses Tobin's $q$ measure. Our results remain robust using these various valuation measures. In fact, the relationship between asset valuations and taxes is substantially more statistically significant using Tobin's $q$ measure than in the base case. This result might be caused by the fact that earnings and dividends are more noisy normalization measures.

Table 7 tests whether the results change using different transformations of the valuation and the tax variables. The first column repeats the results for the base-case specification, and the last column reports the results for a logarithmic specification. A logarithmic specification might be more easily interpretable. For example, a coefficient of one implies a complete tax capitalization. Such a relationship would be consistent with a general equilibrium model without tax changes as shown in Proposition 2. ${ }^{17}$

The results of this logarithmic specification in the fourth column are consistent with the base-case specification. Whereas the coefficient estimate in the fourth column is significantly different from zero, it is not significantly different from one. This indicates that it is not possible to reject a complete tax capitalization using the effective tax rates as the relevant measure of the aggregate tax burden.

\footnotetext{
${ }^{17}$ Proposition 2 indicates in a model with stationary taxes that the price-dividend ratio is $\delta=$ $(1-\tau) \beta \gamma /(1-\beta \gamma)$. Suppose that the dividend-payout ratio is constant over time $d / e=\theta$. Then the price-earnings ratio is $p / e=(1-\tau) \beta \gamma \theta /(1-\beta \gamma)$. Taking logarithms of this relationship gives: $\ln (p / e)=\ln (1-\tau)+\ln (\beta \gamma /(1-\beta \gamma))$, which has the same relationship between valuation levels and taxes as equation (13). A similar relationship occurs in the more general model with tax changes if $\alpha=1$. However, the coefficient will differ from one if $\alpha \neq 1$ and if $\phi<1$, as shown in Proposition 3 .
} 


\subsection{Equity Returns}

This section includes one additional test that investigates the relationship between taxes and asset returns. Proposition 4 indicates that under plausible conditions expected asset returns should be higher in periods of high tax rates. To test whether equity returns are higher during periods of high taxes, I run the following regression:

$$
\begin{aligned}
r_{t}= & \alpha_{0}+\alpha_{1} \tau_{t}+\alpha_{2} r f_{t}+\alpha_{3} \pi_{t}+\alpha_{4} g_{t}+ \\
& \alpha_{5} \text { dem }_{t}+\alpha_{6} r e c_{t}+\alpha_{7} \text { war }_{t}+\alpha_{8} t+\epsilon_{t} .
\end{aligned}
$$

The nominal return of the S\&P Composite index in year $t$ is denoted by $r_{t}$, and the additional control variables are defined as in the previous section. This empirical test uses the effective tax rate with time-varying distribution weights as defined in equation (11), because there is no issue of a spurious correlation if the dependent variable is the asset return. The first column of Table 8 summarizes the coefficient estimates using the contemporaneous return as the dependent variable. The results indicate a statistically significant relationship between taxes and asset returns. Average stock returns tend to be higher in periods of higher tax rates, consistent with the hypothesis that investors are compensated for higher taxes with higher average returns. Thus, before-tax asset returns are higher and asset valuations are lower in periods of relatively higher tax burdens. The higher asset returns during high-tax regimes are simply a consequence of the lower asset valuations.

The second column uses the return in the following year as the dependent variable to avoid any issues of endogeneity. This second specification is related to the literature in finance on the predictability of asset returns. ${ }^{18}$

The coefficients on the tax rates are economically very large. For example, a one percentage point increase in the effective tax rate increases asset returns by

\footnotetext{
${ }^{18}$ See, for example, Campbell and Shiller (1988), Fama and French (1988), Stambaugh (1999) for a discussion of this literature.
} 
between 0.50 and 0.61 percentage points per year. However, the standard errors of this specification are also large, resulting in test statistics with relatively poor power. To increase the power of the tests, one could either increase the number of observations or extend the data set by including some cross-sectional variation. The first strategy of increasing the number of observations is not feasible since tax data are only available over the last century. However, Sialm (2005b) divides up the stocks traded on the major U.S. stock exchanges between 1926 and 2004 into portfolios according to their lagged dividend yield, generating portfolios that should be affected differentially by the time-variations in tax rates, and shows that taxes have a more significant impact for high-dividend stocks that tend to be taxed more heavily. These panel results confirm the hypothesis that taxes have an impact on abnormal asset returns.

\section{Conclusions}

This paper investigates the effective taxation of equity securities and studies whether personal taxes are capitalized in asset prices. The effective personal taxation of equity securities fluctuated considerably since federal taxes were introduced in 1913 . The effective tax rate of stocks decreased over the last 50 years, because statutory tax rates decreased, because the dividend yield decreased, and because a larger fraction of stocks is held today in tax-exempt accounts. The U.S. tax system on equity securities moved gradually from an income-tax system toward a consumption-tax system.

The paper proposes a new empirical test based on the time-series variation in tax burdens to study whether equity taxes are priced. The empirical estimations indicate that aggregate stock valuations tend to be relatively high and asset returns relatively low when taxes are low. This relationship remains robust after controlling for additional macroeconomic variables. These results confirm the results of McGrattan and 
Prescott (2005), who find in a calibrated growth model that asset valuations increased significantly between 1960-2000 due to various tax and regulatory reforms.

Taxes appear to be one of the factors that drive valuation levels of the aggregate stock market. It must be kept in mind that taxes do not explain all the variation in asset valuations and that changes in risk, changes in risk-aversion, and changes in investor sentiment probably also account for a significant portion of the variability in asset valuations over the last century. 


\section{References}

Allen, F. and R. Michaely (2003). Payout policy. In G. M. Constantinides, M. Harris, and R. M. Stulz (Eds.), Handbook of the Economics of Finance Volume $1 \mathrm{~A}$ Corporate Finance, pp. 337-429. Amsterdam: Elsevier North-Holland.

Auerbach, A. J. (1979). Share valuation and corporate equity policy. Journal of Public Economics 11(3), 291-305.

Auerbach, A. J. (2002). Taxation and corporate financial policy. In A. J. Auerbach and M. S. Feldstein (Eds.), Handbook of Public Economics Vol. 3, pp. 12511292. Amsterdam: North Holland.

Auerbach, A. J., L. E. Burman, and J. M. Siegel (2000). Capital gains taxation and tax avoidance: New evidence from panel data. In J. Slemrod (Ed.), Does Atlas Shrug? The Economic Consequences of Taxing the Rich. Cambridge, MA: Harvard University Press.

Auerbach, A. J. and K. A. Hassett (2005). The 2003 dividend tax cuts and the value of the firm: An event study. NBER Working Paper 11449.

Barclay, M. J. (1987). Dividends, taxes, and common stock prices: The ex-dividend day behavior of common stock prices before the income tax. Journal of Financial Economics 19(1), 31-44.

Black, F. and M. Scholes (1974). The effects of dividend yield and dividend policy on common stock prices and returns. Journal of Financial Economics 1(1), $1-22$.

Blanchard, O., C. Rhee, and L. Summers (1993). The stock market, profit, and investment. Quarterly Journal of Economics 108(1), 115-136.

Blume, M. E. (1980). Stock return and dividend yield: Some more evidence. Review of Economics and Statistics 62(1), 1-22.

Bradford, D. F. (1981). The incidence and allocation effects of a tax on corporate distributions. Journal of Public Economics 15(1), 1-22.

Brennan, M. J. (1970). Taxes, market valuation, and financial policy. National Tax Journal 23, 417-429.

Burman, L. E. (1999). The Labyrinth of Capital Gains Tax Policy. A Guide for the Perplexed. Washington: Brookings.

Campbell, J. Y. and R. J. Shiller (1988). Stock prices, earnings, and expected dividends. Journal of Finance 43(6), 661-676.

Campbell, J. Y. and R. J. Shiller (1998). Valuation ratios and the long-run stock market outlook. Journal of Portfolio Management 24(2), 11-26.

Chaplinsky, S. and H. N. Seyhun (1990). Dividends and taxes: Evidence from tax-reduction strategies. Journal of Business 63(2), 239-260.

Chetty, R., J. Rosenberg, and E. Saez (2005). The effects of taxes on market responses to dividend announcements and payments: What can we learn from the 2003 tax cut. NBER Working Paper 11452. 
Constantinides, G. (1983). Capital market equilibrium with personal tax. Econometrica 51(3), 611-636.

Constantinides, G. (1984). Optimal stock trading with personal taxes. Journal of Financial Economics 13, 65-89.

Dammon, R. M. and C. S. Spatt (1996). The optimal trading and pricing of securities with asymmetric capital gains taxes and transaction costs. Review of Financial Studies 9(3), 921-952.

Desai, M. A. and A. D. Goolsbee (2004). Investment, overhang, and tax policy. Brookings Papers on Economic Activity 35(2), 285-338.

Dodd, D. B. (1993). Historical Statistics of the States of the United States. Two Centuries of the Census 1790-1990. Westport: Greenwood.

Eades, K. M., P. J. Hess, and E. H. Kim (1984). On interpreting security returns during the ex-dividend period. Journal of Financial Economics 13, 3-34.

Elton, E. J. and M. J. Gruber (1970). Marginal stockholder tax rates and the clientele effect. Review of Economics and Statistics 52(1), 68-74.

Elton, E. J., M. J. Gruber, and C. R. Blake (2005). Marginal stockholder tax effects and ex-dividend day behavior: Evidence from taxable versus non-taxable closed-end funds. Forthcoming: Review of Economics and Statistics.

Fama, E. F. and K. R. French (1988). Dividend yields and expected stock returns. Journal of Political Economy 96, 246-273.

Fama, E. F. and K. R. French (1998). Taxes, financing decisions, and firm value. Journal of Finance 53(3), 819-843.

Feenberg, D. and E. Coutts (1993). An introduction to the TAXSIM model. Journal of Policy Analysis and Management 12(1), 189-194.

Frank, M. and R. Jagannathan (1998). Why do stock prices drop by less than the value of the dividend? Evidence from a country without taxes. Journal of Financial Economics 47(2), 161-188.

Gordon, R. H. and D. F. Bradford (1980). Taxation and the stock market value of capital gains and dividends: Theory and empirical results. Journal of Public Economics 14(2), 109-136.

Graham, J. R., R. Michaely, and M. R. Roberts (2003). Do price discreteness and transactions costs affect stock returns? Comparing ex-dividend pricing before and after decimalization. Journal of Finance 58(6), 2611-2636.

Green, R. C. and K. Rydqvist (1999). Ex-day behavior with dividend preference and limitations to short-term arbitrage: The case of Swedish lottery bonds. Journal of Financial Economics 53(2), 145-187.

Harris, T. S., R. G. Hubbard, and D. Kemsley (2001). The share price effects of dividend taxes and tax imputation credits. Journal of Public Economics 79(3), $569-596$. 
Internal Revenue Service (Ed.) (1954). Statistics of Income. Washington D.C.: U.S. Treasury Department.

Ivkovich, Z., J. Poterba, and S. Weisbenner (2005). Tax-motivated trading by individual investors. Forthcoming: American Economic Review.

Joint Committee on Taxation (1988-1998). General Explanation of Tax Legislation. Washington D.C.: U.S. Government Printing Office.

King, M. A. (1977). Public Policy and the Corporation. London: Chapman and Hall.

Litzenberger, R. H. and K. Ramaswamy (1979). The effects of personal taxes and dividends on capital asset prices: Theory and empirical evidence. Journal of Financial Economics 7, 163-195.

Lucas, R. E. (1978). Asset prices in an exchange economy. Econometrica 46(6), $1429-1445$.

McDonald, R. L. (2004). Portfolio choice and corporate financial policy when there are tax-intermediating dealers. Northwestern University.

McGrattan, E. R. and E. C. Prescott (2005). Taxes, regulations, and the value of U.S. and U.K. corporations. Review of Economic Studies 72(3), 767-796.

Michaely, R. (1991). Ex-dividend day stock price behavior: The case of the 1986 tax reform act. Journal of Finance 46(3), 845-859.

Miller, M. H. and M. S. Scholes (1978). Dividends and taxes. Journal of Financial Economics 6(4), 333-364.

Miller, M. H. and M. S. Scholes (1982). Dividends and taxes: Some empirical evidence. Journal of Political Economy 90(6), 1118-1141.

Mitchell, B. (1983). International Historical Statistics: The Americas and Australasia. Michigan: Gale Research.

Naranjo, A., M. Nimalendran, and M. Ryngaert (1998). Stock returns, dividend yields, and taxes. Journal of Finance 53(6), 2029-2057.

Newey, W. and K. West (1987). A simple, positive, semi-definite, heteroskedasticity and autocorrelation consistent covariance matrix. Econometrica 1987(55), 703708.

Pechman, J. A. (1987). Federal Tax Policy (5th ed.). Washington D.C.: Brookings.

Poterba, J. M. (1987a). How burdensome are capital gains taxes? Evidence from the United States. Journal of Public Economics 33(2), 157-172.

Poterba, J. M. (1987b). Tax policy and corporate saving. Brookings Papers on Economic Activity 1987(2), 455-503.

Poterba, J. M. (1998). The rate of return to corporate capital and factor shares: New estimates using revised national income accounts and capital stock data. Carnegie-Rochester Conference Series on Public Policy 48, 211-246. 
Poterba, J. M. (2000). Stock market wealth and consumption. Journal of Economic Perspectives 14(2), 99-118.

Poterba, J. M. (2002). Taxation, risk-taking, and household portfolio behavior. In A. J. Auerbach and M. S. Feldstein (Eds.), Handbook of Public Economics Vol. 3, pp. 1109-1171. Amsterdam: North Holland.

Poterba, J. M. and L. H. Summers (1984). New evidence that taxes affect the valuation of dividends. Journal of Finance 39(5), 1397-1415.

Poterba, J. M. and L. H. Summers (1985). The economic effects of dividend taxation. In E. Altman and M. Subrahmanyam (Eds.), Recent Advances in Corporate Finance, pp. 227-284. Homewood, IL: Dow Jones-Irwin Publishing.

Santa-Clara, P. and R. Valkanov (2002). The presidential puzzle: Political cycle and the stock market. Journal of Finance 58(5), 1841-1872.

Shiller, R. J. (1989). Market Volatility. Cambridge: MIT.

Sialm, C. (2005a). Stochastic taxation and asset pricing in dynamic general equilibrium. Forthcoming: Journal of Economic Dynamics and Control.

Sialm, C. (2005b). Tax changes and asset pricing: Cross-sectional evidence. University of Michigan.

Stambaugh, R. F. (1999). Predictive regressions. Journal of Financial Economics 54, 375-421.

Stiglitz, J. E. (1983). Some aspects of the taxation of capital gains. Journal of Public Economics 21(2), 257-294. 


\section{A Proofs}

\section{A.1 Proof of Proposition 1}

The price-dividend ratio from equation (9) can be expressed as:

$$
\begin{aligned}
\delta_{H} & =\beta \gamma\left[\phi\left(\delta_{H}+\left(1-\tau_{H}\right)\right)+(1-\phi)\left(\delta_{L}+\left(1-\tau_{L}\right)\right) \eta\right] \\
\delta_{L} & =\beta \gamma\left[\phi\left(\delta_{L}+\left(1-\tau_{L}\right)\right)+(1-\phi)\left(\delta_{H}+\left(1-\tau_{H}\right)\right) / \eta\right] .
\end{aligned}
$$

where $\gamma=E_{t}\left[\left(d_{t+1} / d_{t}\right)^{1-\alpha}\right]=\exp \left((1-\alpha) \mu+0.5(1-\alpha)^{2} \sigma^{2}\right)$ and $\eta=[(1-$ $\left.\left.\tau_{L}\right) /\left(1-\tau_{H}\right)\right]^{-\alpha}$. This simplification is possible because of the independence between the tax and the dividend process.

Equations (15) and (16) can be solved in closed form for the two price-dividend ratios. These equations can be written in matrix form, where $\delta=\left[\begin{array}{ll}\delta_{H} & \delta_{L}\end{array}\right]^{\prime}$ :

$$
\mathbf{A} \delta=\mathbf{b}
$$

where:

$$
\begin{gathered}
\mathbf{A}=\left[\begin{array}{cc}
1-\beta \gamma \phi & -\beta \gamma(1-\phi) \eta \\
-\beta \gamma(1-\phi) / \eta & 1-\beta \gamma \phi
\end{array}\right], \\
\mathbf{b}=\left[\begin{array}{c}
\beta \gamma\left(\phi\left(1-\tau_{H}\right)+(1-\phi)\left(1-\tau_{L}\right) \eta\right) \\
\beta \gamma\left(\phi\left(1-\tau_{L}\right)+(1-\phi)\left(1-\tau_{H}\right) / \eta\right)
\end{array}\right] .
\end{gathered}
$$

The price-dividend ratio can be solved in closed form if $\mathbf{A}$ is nonsingular. The determinant $|\mathbf{A}|$ is:

$$
\begin{aligned}
|\mathbf{A}| & =(1-\beta \gamma \phi)^{2}-(\beta \gamma)^{2}(1-\phi)^{2} \\
& =(1-\beta \gamma)[(1-\beta \gamma \phi)+\beta \gamma(1-\phi)] .
\end{aligned}
$$

The determinant $|\mathbf{A}|$ is strictly positive whenever $0<\beta \gamma<1$. As long as riskaversion and the moments of the growth rate are finite, $\beta \gamma=\beta \exp [(1-\alpha) \mu+0.5(1-$ $\left.\alpha)^{2} \sigma^{2}\right]>0$. Furthermore, the transversality condition (7) is violated if $\beta \gamma \geq 1$. Thus, for prices to be finite, we need to require that $\beta \gamma<1$.

The closed-form solutions for the price-dividend ratios are:

$$
\delta=\mathbf{A}^{-1} \mathbf{b}
$$

The price-dividend ratios in the two regimes are as follows:

$$
\begin{aligned}
\delta_{H} & =\frac{\beta \gamma\left[(\phi(1-\beta \gamma)+(1-\phi)(\beta \gamma))\left(1-\tau_{H}\right)+(1-\phi)\left(1-\tau_{L}\right) \eta\right]}{(1-\beta \gamma)[(1-\beta \gamma \phi)+\beta \gamma(1-\phi)]}, \\
\delta_{L} & =\frac{\beta \gamma\left[(\phi(1-\beta \gamma)+(1-\phi)(\beta \gamma))\left(1-\tau_{L}\right)+(1-\phi)\left(1-\tau_{H}\right) / \eta\right]}{(1-\beta \gamma)[(1-\beta \gamma \phi)+\beta \gamma(1-\phi)]} .
\end{aligned}
$$

The price-dividend ratios are strictly positive whenever $0<\beta \gamma<1$. 
Next, I compare the valuation levels in the two regimes. The denominators are identical for the two valuation ratios. The first term in brackets for equation (19) is smaller than the first term for equation $(20)(\phi(1-\beta \gamma)+(1-\phi)(\beta \gamma))\left(1-\tau_{H}\right)<$ $(\phi(1-\beta \gamma)+(1-\phi)(\beta \gamma))\left(1-\tau_{L}\right)$, as long as $\tau_{H}>\tau_{L}$. The second term in brackets for equation (19) is smaller than the second term for equation (20) if $\alpha>0.5$. Note that $\left(1-\tau_{L}\right) \eta=\left(1-\tau_{L}\right)\left[\left(1-\tau_{L}\right) /\left(1-\tau_{H}\right)\right]^{-\alpha}=\left(1-\tau_{L}\right)^{1-\alpha}\left(1-\tau_{H}\right)^{\alpha}$ and $\left(1-\tau_{H}\right) / \eta=$ $\left(1-\tau_{H}\right)\left[\left(1-\tau_{H}\right) /\left(1-\tau_{L}\right)\right]^{-\alpha}=\left(1-\tau_{H}\right)^{1-\alpha}\left(1-\tau_{L}\right)^{\alpha}$. The second term is identical in the two equations if $\alpha=0.5$ and is smaller in equation (19) if $\alpha>0.5$. Thus, $\delta_{H}<\delta_{L}$ if $\alpha>0.5$.

To show the general conditions for the asset valuations in the two tax regimes, we only need to take into account the numerators of equations (19) and (20), since the denominators are identical and positive. The inequality $\delta_{H} \lesseqgtr \delta_{L}$ results if:

$$
\begin{array}{ll} 
& (\phi(1-\beta \gamma)+(1-\phi)(\beta \gamma))\left(1-\tau_{H}\right)+(1-\phi)\left(1-\tau_{L}\right) \eta \\
\lesseqgtr & (\phi(1-\beta \gamma)+(1-\phi)(\beta \gamma))\left(1-\tau_{L}\right)+(1-\phi)\left(1-\tau_{H}\right) / \eta .
\end{array}
$$

It is possible to re-write this inequality using:

$$
\phi(x+y) \lesseqgtr x,
$$

where:

$$
\begin{aligned}
& x=\beta \gamma\left(\tau_{H}-\tau_{L}\right)+\left(1-\tau_{H}\right) / \eta-\left(1-\tau_{L}\right) \eta, \\
& y=\beta \gamma\left(\tau_{H}-\tau_{L}\right)+\left(1-\tau_{H}\right)-\left(1-\tau_{L}\right) .
\end{aligned}
$$

Note that $y$ is always negative since $y=\beta \gamma\left(\tau_{H}-\tau_{L}\right)+\left(1-\tau_{H}\right)-\left(1-\tau_{L}\right)=$ $(\beta \gamma-1)\left(\tau_{H}-\tau_{L}\right)$. Also note that $y \leq x$ since $\eta=\left(\left(1-\tau_{L}\right) /\left(1-\tau_{H}\right)\right)^{-\alpha} \leq 1$.

We need to distinguish between two cases, depending on whether $x+y$ is positive or negative. Case 1 has $x+y<0$. In this case, $\delta_{H} \lesseqgtr \delta_{L}$ if $\phi \gtreqless x /(x+y)$. If $x<0$, then $x /(x+y)>0$ and since $y \leq x$ it must be that $x /(x+y) \leq 0.5$. On the other hand, if $x>0$, then $x /(x+y)<0$ and $\delta_{H}<\delta_{L}$ for all probabilities $\phi \in[0,1]$.

Case 2 has $x+y \geq 0$. In this case, $\delta_{H} \lesseqgtr \delta_{L}$ if $\phi \lesseqgtr x /(x+y)$. Since $x+y \geq 0$ and $y<0$, it must be that $x>0$. Thus, $x /(x+y)>1$ and $\delta_{H}<\delta_{L}$ for all probabilities $\phi \in[0,1]$.

Thus, these results indicate that $\delta_{H}<\delta_{L}$ for all cases, except for the case where $x<0$ and $\phi<x /(x+y) \leq 0.5$. Thus, $\delta_{H} \lesseqgtr \delta_{L}$ if $\phi \gtreqless \tilde{\phi}$, where the critical persistence level is defined as:

$$
\tilde{\phi}= \begin{cases}-\infty & \text { if } x+y \geq 0 \\ x /(x+y) & \text { if } x+y<0\end{cases}
$$

\section{A.2 Proof of Proposition 2}

If taxes are permanent $(\phi=1)$, then the price-dividend ratio equals:

$$
\delta_{t}=\sum_{i=1}^{\infty} E_{t}\left[\beta^{i} \frac{u^{\prime}\left(c_{t+i}\right)}{u^{\prime}\left(c_{t}\right)} \frac{(1-\tau) d_{t+i}}{d_{t}}\right],
$$




$$
=(1-\tau) \sum_{i=1}^{\infty}\left[(\beta \gamma)^{i}\right]=(1-\tau) \frac{\beta \gamma}{1-\beta \gamma},
$$

\section{A.3 Proof of Proposition 3}

Equations (19) and (20) describe the asset valuations in the two states. The ratio of the asset valuation is given by:

$$
\begin{aligned}
\frac{\delta_{L}}{\delta_{H}} & =\frac{(\phi(1-\beta \gamma)+(1-\phi)(\beta \gamma))\left(1-\tau_{L}\right)+(1-\phi)\left(1-\tau_{H}\right) / \eta}{(\phi(1-\beta \gamma)+(1-\phi)(\beta \gamma))\left(1-\tau_{H}\right)+(1-\phi)\left(1-\tau_{L}\right) \eta} \\
& =\left(\frac{1-\tau_{L}}{1-\tau_{H}}\right)\left[\frac{(\phi(1-\beta \gamma)+(1-\phi)(\beta \gamma))+(1-\phi)\left(\frac{1-\tau_{H}}{1-\tau_{L}}\right)^{1-\alpha}}{(\phi(1-\beta \gamma)+(1-\phi)(\beta \gamma))+(1-\phi)\left(\frac{1-\tau_{L}}{1-\tau_{H}}\right)^{1-\alpha}}\right]
\end{aligned}
$$

Note that if $\alpha \lesseqgtr 1$, then $\left[\left(1-\tau_{L}\right) /\left(1-\tau_{H}\right)\right]^{1-\alpha} \gtreqless 1$ and $\left[\left(1-\tau_{H}\right) /\left(1-\tau_{L}\right)\right]^{1-\alpha} \lesseqgtr 1$. Thus, the numerator in brackets is smaller (larger) than the denominator whenever $\alpha<1(\alpha>1)$. With log-utility $(\alpha=1)$, the ratio between the two prices is just $\delta_{L} / \delta_{H}=\left(1-\tau_{L}\right) /\left(1-\tau_{H}\right)$.

\section{A.4 Proof of Proposition 4}

The expected returns in the two tax regimes are as follows:

$$
\begin{aligned}
\lambda_{H} & =\xi\left[\phi \frac{\delta_{H}+1}{\delta_{H}}+(1-\phi) \frac{\delta_{L}+1}{\delta_{H}}\right] \\
\lambda_{L} & =\xi\left[\phi \frac{\delta_{L}+1}{\delta_{L}}+(1-\phi) \frac{\delta_{H}+1}{\delta_{L}}\right] .
\end{aligned}
$$

where $\xi=E_{t}\left[\left(d_{t+1} / d_{t}\right)\right]=\exp \left(\mu+0.5 \sigma^{2}\right)$.

Equations (22) and (23) describe expected returns in the two states. If $\delta_{H} \lesseqgtr \delta_{L}$ then $\left(\delta_{H}+1\right) / \delta_{H} \gtreqless\left(\delta_{L}+1\right) / \delta_{L}$ and $\left(\delta_{L}+1\right) / \delta_{H} \gtreqless\left(\delta_{H}+1\right) / \delta_{L}$. Thus, if $\delta_{H} \lesseqgtr \delta_{L}$ then $\lambda_{H} \gtreqless \lambda_{L}$.

\section{B Data}

This section explains in more detail the computation of the effective tax rates.

\section{B.1 Statutory Tax Rates}

Taxable income is derived for five real income levels after deducting exemptions for a married couple filing jointly with two dependent children from the fixed income levels. The proportion of total deductions relative to the adjusted gross income is assumed to equal the proportion of total deductions in the whole population for each year as reported by the Internal Revenue Service. 
The marginal income tax brackets and exemptions are determined using the Statistics of Income of the Internal Revenue Service (1954) for the years 1913-1943, Pechman (1987) for the years 1944-1987, and different issues of the Instructions to Form 1040 from the IRS for the remaining years between 1988-2004. The values of the Consumer Price Index from 1913-1957 are taken from the Bureau of Labor Statistics. ${ }^{19}$ Total deductions as a proportion of adjusted gross income (AGI) are derived from different issues of the Statistics of Income of the IRS. Marginal income tax rates for individuals in five different tax brackets corresponding to Adjusted Gross Income levels of 50, 100, 250, 500 thousand U.S. dollars (with 2004 consumer prices), as well as the highest marginal income tax rate are derived.

The long-term capital gains tax rate applies to realized gains with a holding period of more than five years. The data source for the capital gains tax rates for 1913-1950 is the Synopsis of Federal Tax Laws from the Statistics of Income for 1950. The remaining tax rates are taken from different issues of the General Explanations of Tax Legislation by the Joint Committee on Taxation (1998) and Table 2-4 from Burman (1999).

\section{B.2 Average Marginal Tax Rates}

The time series for the average marginal tax rates of dividends, capital gains, interest income, and wage income are computed using different annual issues of the Statistics of Income between 1917 and 1964 and the average marginal tax rates from the National Bureau of Economic Research between 1965-2004. Post-2001 data is derived from the 2000 Tax Model, since these years are not yet available from the SOI. However, the data includes the impact of EGGTRA and JGTRRA and reflects therefore the tax changes through January 2005. The NBER publishes average marginal tax rates for selected income sources since 1960 using their Taxsim software. ${ }^{20}$

The NBER publishes average marginal tax rates that include state and local taxes. For the early data, I use the National Income and Product Accounts published by the Bureau of Economic Analysis to determine the state and local tax rates. The BEA summarizes the current personal income tax receipts of state and local governments (Table 3.3) and the federal government (Table 3.2). ${ }^{21} \mathrm{I}$ assume that the state and local government tax rate is a fixed proportion of the federal tax rate according to the annual revenues.

The proportion of equity held in taxable accounts is estimated using the Flow of Funds published by the Board of Governors of the Federal Reserve Bank. ${ }^{22}$ The proportion is only computed for equities held by domestic investors, since it would be impossible to determine the marginal tax rates faced by international stock investors. The detailed derivation of the time series is available upon request. The flow of funds publishes this distribution of equity holdings only between 1945 and 2001. The values prior to 1945 and after 2001 are taken from the most recent available year.

\footnotetext{
${ }^{19}$ Data can be found at http://www.bls.gov/cpi/home.htm.

${ }^{20}$ The time series can be downloaded from http://www.nber.org/ taxsim.

${ }^{21}$ The data can be downloaded from http://www.bea.gov.

${ }^{22}$ The data can be downloaded from http://www.federalreserve.gov/releases/Z1/.
} 
The tax rates $\tau_{d i v}, \tau_{s c g}$, and $\tau_{l c g}$ from equations (11) and (12) are computed by multiplying the average marginal tax rates of taxable investors given in Figure 4 with the proportion of equity held in taxable accounts. This assumes that assets held in retirement accounts and by tax-exempt institutions face a zero effective tax rate. ${ }^{23}$

\section{B.3 Distributions of Dividends and Capital Gains}

The proportion of dividend distributions $w_{t}^{\text {div }}$ is computed as the ratio of the dividend yield $y_{t}^{d i v}$ and the average real stock return $E(r)$ :

$$
w_{t}^{d i v}=\frac{y_{t}^{d i v}}{E(r)} .
$$

The average proportion of dividend distributions equals 43.06 percent and ranges between 11.85 (1999) and 85.45 (1950) percent.

The short- and long-term capital gains yields $y_{t}^{s c g}$ and $y_{t}^{l c g}$ are defined as the product between the dividend yield $y_{t}^{d i v}$ and the ratio between the short- and longterm realized capital gains $S C G_{t}$ and $L C G_{t}$ divided by the total dividend payments $D_{t}$, as reported by the IRS:

$$
\begin{aligned}
y_{t}^{l c g} & =y_{t}^{d i v} \frac{L C G_{t}}{D_{t}} \\
y_{t}^{s c g} & =y_{t}^{d i v} \frac{S C G_{t}}{D_{t}}
\end{aligned}
$$

The annual Statistics of Income of the Internal Revenue Service report for most years in our sample the total short- and long-term capital gains and the dividends declared by individuals. The capital gains given by the Statistics of Income include capital gains from many sources and not just from stock transactions. The IRS does unfortunately not report every year the proportion of capital gains that result from transactions of corporate equities. However, for eight years between 1959 and 2004, the IRS reported the sources of capital gains in more detail. On average, about 35 percent of the capital gains result from transactions of corporate equity. I interpolated the fraction of stock capital gains using these eight years.

The average value of the proportion of short-term capital gains is -1.38 , and the proportion of long-term capital gains equals 24.96 percent. On average, 66.64 percent of the expected real returns are either realized as dividends or as capital gains.

The capital gains realizations vary substantially through time. For example, long-

\footnotetext{
${ }^{23}$ Asset returns remain untaxed in tax-preferred accounts, such as ROTH-IRA accounts, as long as investors do not take non-qualified distributions. However, the returns in tax-deferred savings accounts, such as regular IRAs and 401(k) accounts, are not completely tax-exempt. Contributions to tax-deferred accounts are deducted from taxable income while the total withdrawals are taxed at the ordinary income tax rate. If investors remain in the same tax bracket throughout their lifetimes, then savings in a tax-deferred account accumulate completely tax-free. If investors are in a lower (higher) tax bracket during retirement compared to before retirement, then they face effectively negative (positive) taxes on their accumulated savings in a tax-deferred account.
} 
term capital gains are extremely high in 1986, before the enactment of the TRA of 1986, where capital gains taxes were increased from 20 to 28 percent. Moreover, short-term capital loss realizations are relatively high in the early 2000s due to the large decline in stock prices during that period. To eliminate the impact of these high-frequency changes in capital gains realization, it is assumed that investors have a fixed propensity to realize capital gains and capital losses over the sample period out of the total capital gains. Thus, the proportions of the short- and long-run capital gains distributions $w_{k t}^{s c g}$ and $w_{t}^{l c g}$ are given by the following equation:

$$
\begin{aligned}
w_{t}^{l c g} & =\frac{\bar{y}^{l c g}}{E(r)} \frac{1-w_{t}^{d i v}}{1-\bar{w}^{d i v}}, \\
w_{t}^{s c g} & =\frac{\bar{y}^{s c g}}{E(r)} \frac{1-w_{t}^{d i v}}{1-\bar{w}^{d i v}},
\end{aligned}
$$

where $\bar{w}^{d i v}$ denotes the average proportion of returns distributed as dividends, and $\bar{y}^{l c g}$ and $\bar{y}^{s c g}$ denote the average long- and short-term capital gains yields over the whole sample period. However, our regression results are not affected qualitatively if we use the actual annual capital gains realizations instead (e.g., $w_{t}^{l c g}=y_{t}^{l c g} / E(r)$ and $\left.w_{t}^{s c g}=y_{t}^{s c g} / E(r)\right)$.

\section{B.4 Macroeconomic Data}

The S\&P Composite Index Value, the corresponding dividend and earnings variables, the consumer price index, and the interest rates series between 1913 and 2005 used in Section 4 are taken from Robert Shiller's webpage. ${ }^{24}$ The stock prices are the average values in January of the Standard and Poor's Composite index. The dividends and the earnings per share are adjusted to the S\&P Composite index (4 Quarter Total). Tobin's $q$ is computed following Blanchard, Rhee, and Summers (1993). The nominal output growth rate is computed using the growth rate in the GNP from Mitchell (1983) prior to 1928 and the growth rate in the GDP from the BEA (Table 1.1 Line 1; http://www.bea.gov). The U.S. population prior to 1940 is taken from Dodd (1993) and after 1939 from the BEA (Table 8.7 Line 16; http://www.bea.gov). The party of the president was found on http://www.whitehouse.gov/history/presidents/. The NBER recessions are obtained from http://www.nber.org/cycles/. World War I (1914-1918), World War II (1941-1945), the Korean War (1950-1953), and the Vietnam War (1965-1972) are counted as war years.

\footnotetext{
${ }^{24}$ See http://aida.econ.yale.edu/ shiller/.
} 
Figure 1: Price-Dividend Ratio

These figures depict the price-dividend ratio $\delta$ in the two tax regimes at four different risk-aversion levels.
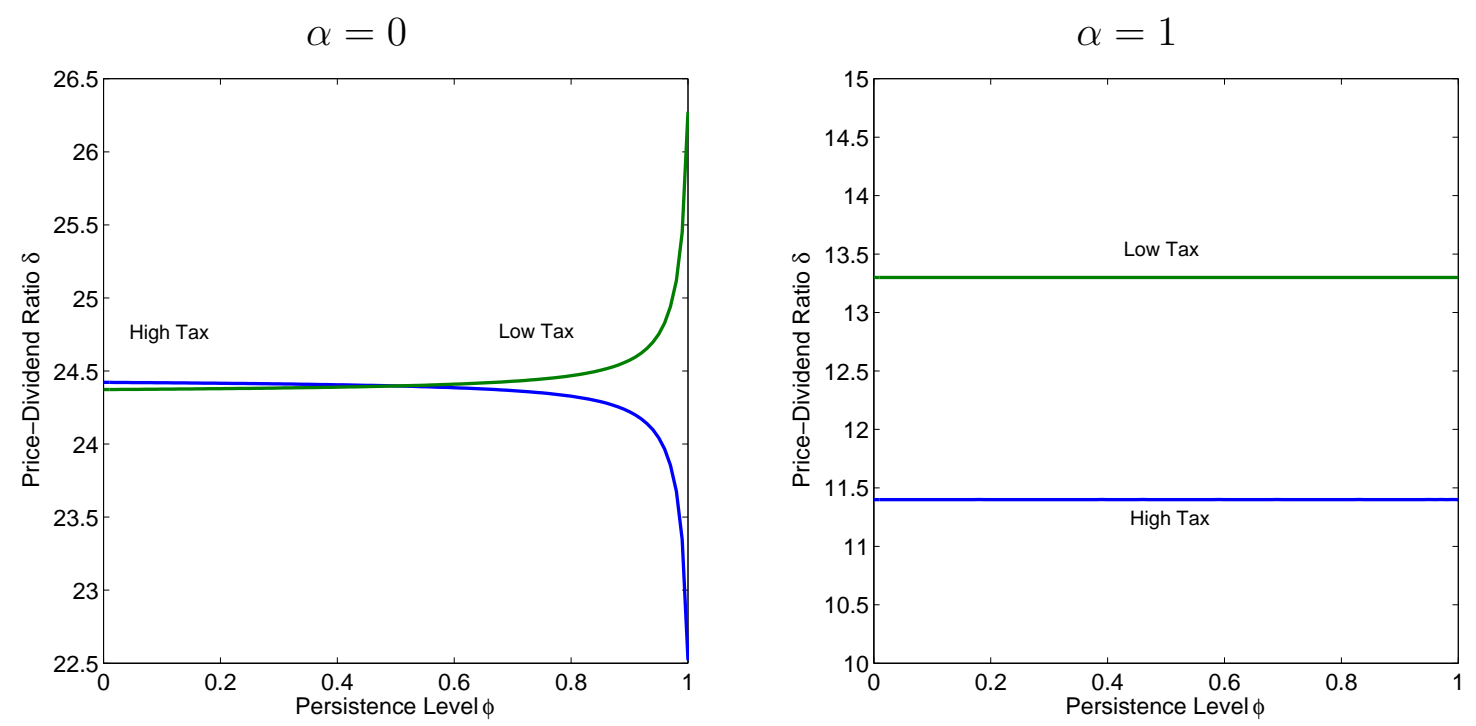

$\alpha=3$
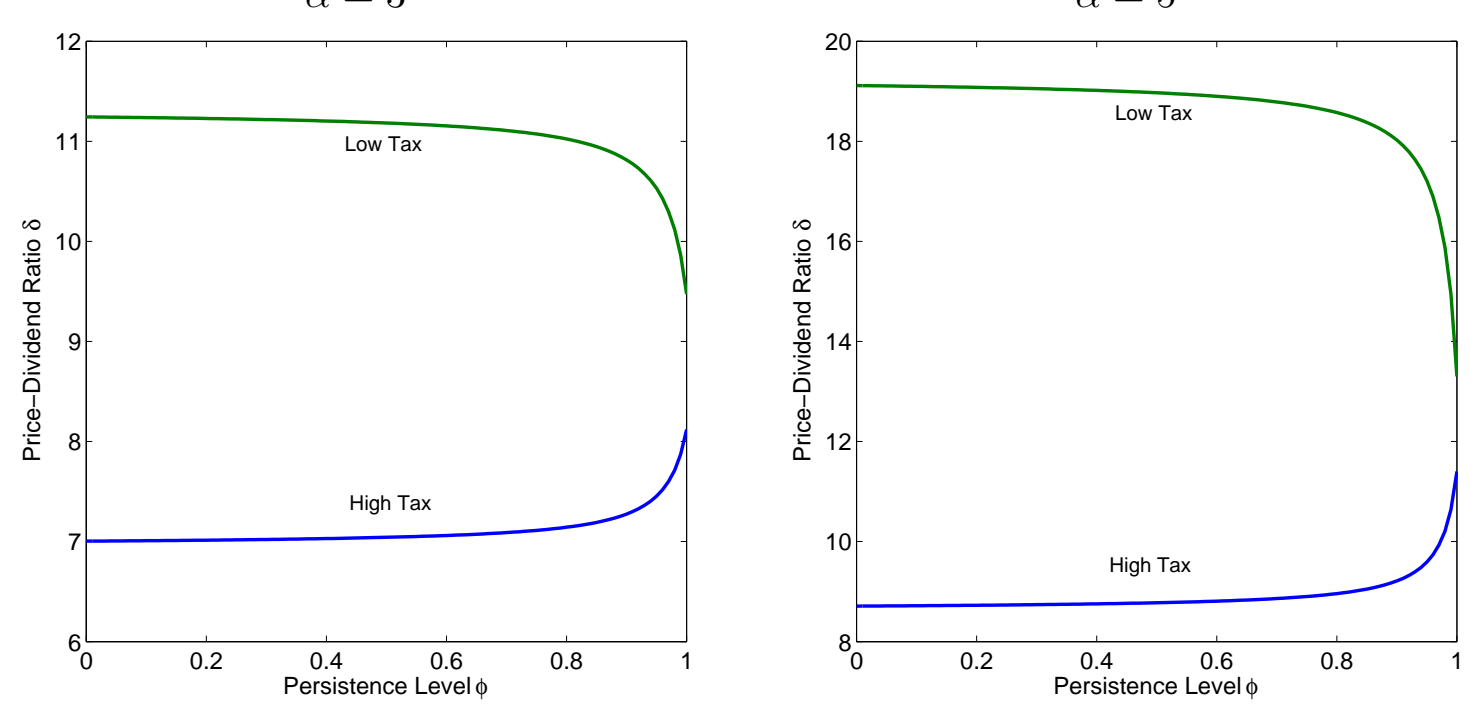
Figure 2: Expected Asset Returns

These figures depict the expected returns in the two tax regimes at four different risk-aversion levels.
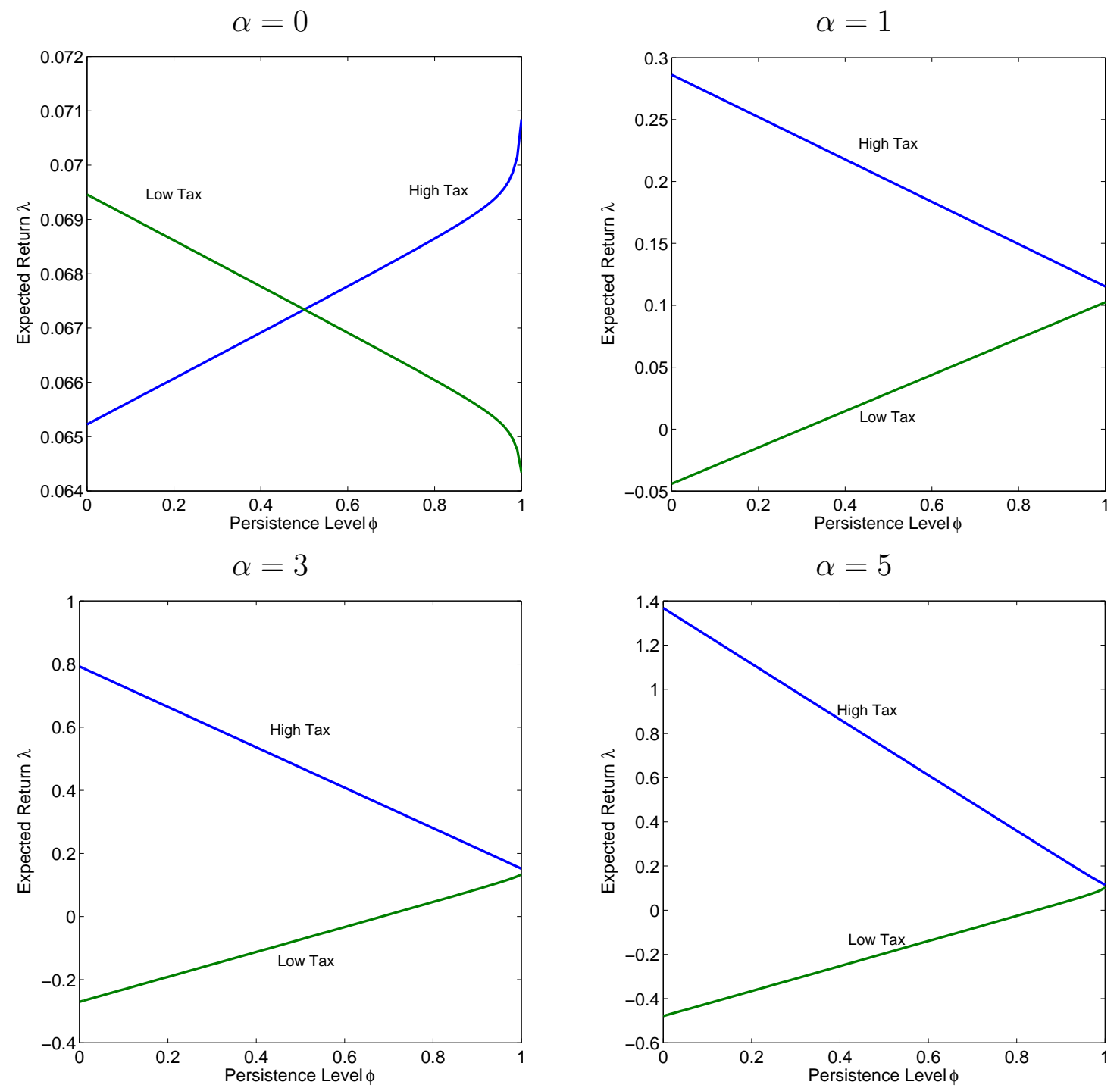
Figure 3: Statutory Federal Marginal Income Tax Rates at Different Real Income Levels

The marginal income tax rates are depicted over the period from 1913 to 2004 for five different real income levels. The four lower curves correspond to the marginal income tax rates for households with real income levels of 50, 100, 250, and 500 thousand U.S. dollars expressed in 2004 consumer prices. The highest curve corresponds to the maximum marginal income tax rate.

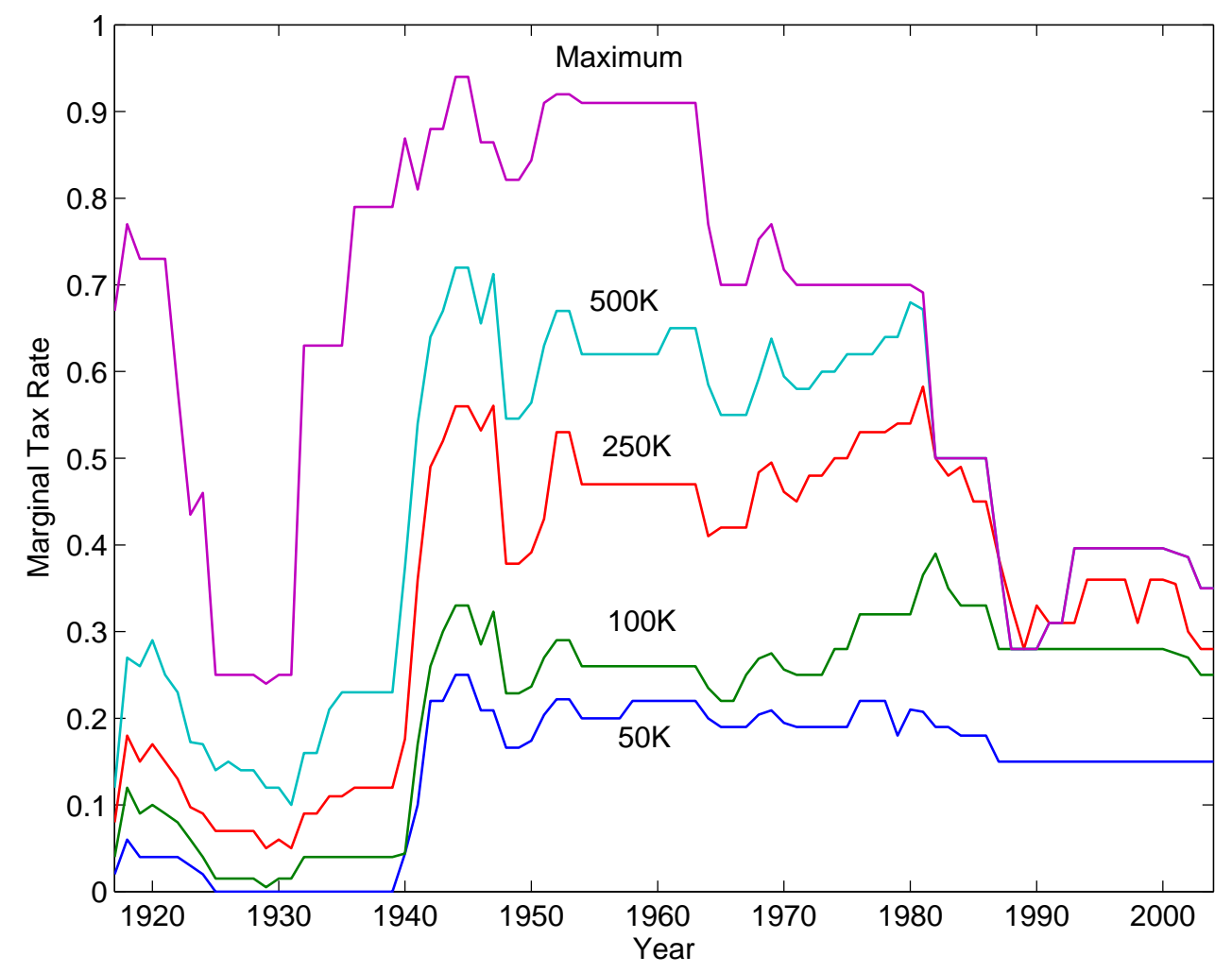


Figure 4: Average Marginal Investment Income Tax Rates for Taxable Investors The dollar-weighted average marginal tax rates for taxable investors on dividend income and capital gains are depicted between 1917 and 2004. The tax rates include taxes imposed by state and local governments.

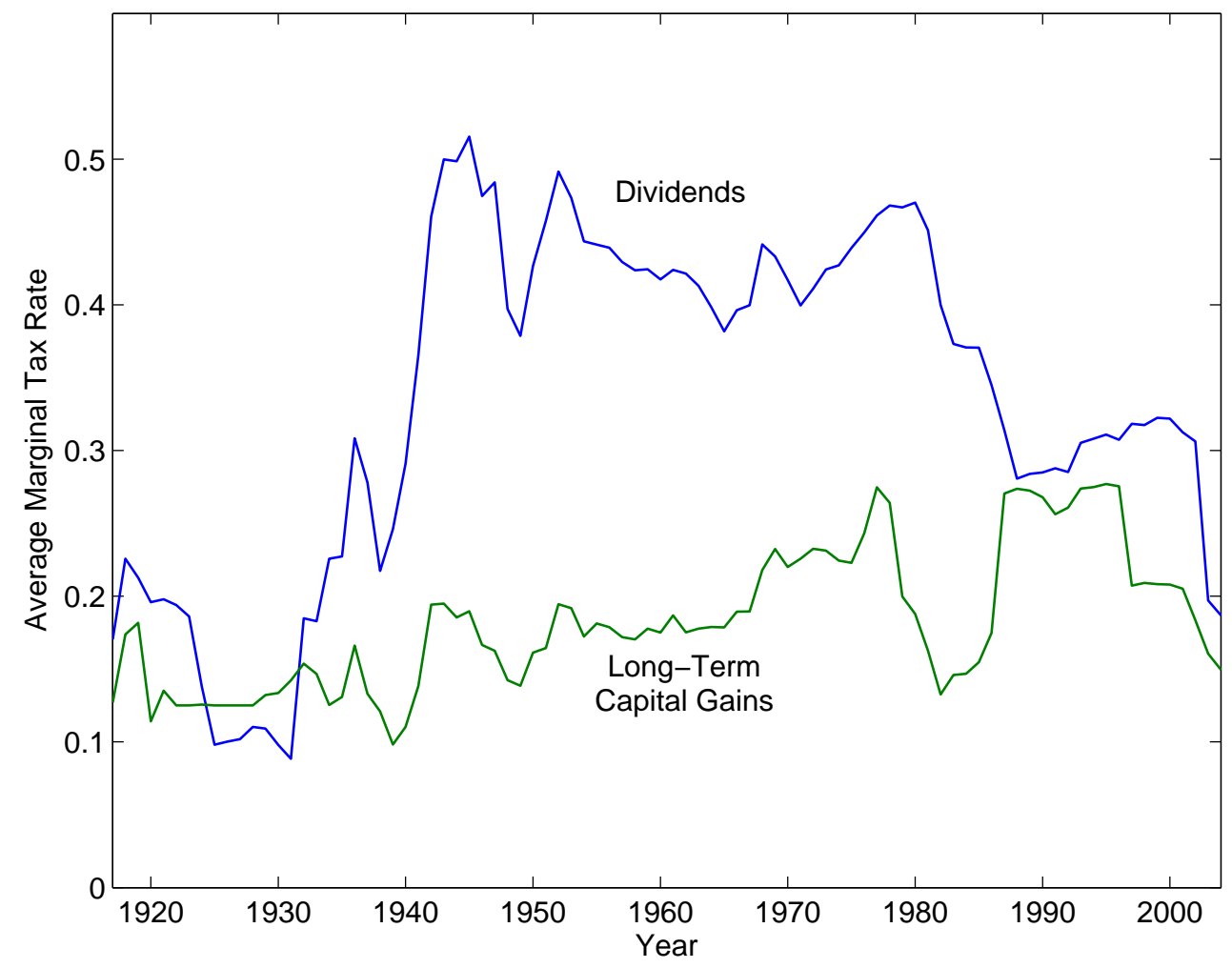


Figure 5: Dividend and Capital Gains Realizations

These figures depict the total dividend and the capital gains realizations on the U.S. stock market divided by the initial market capitalization.
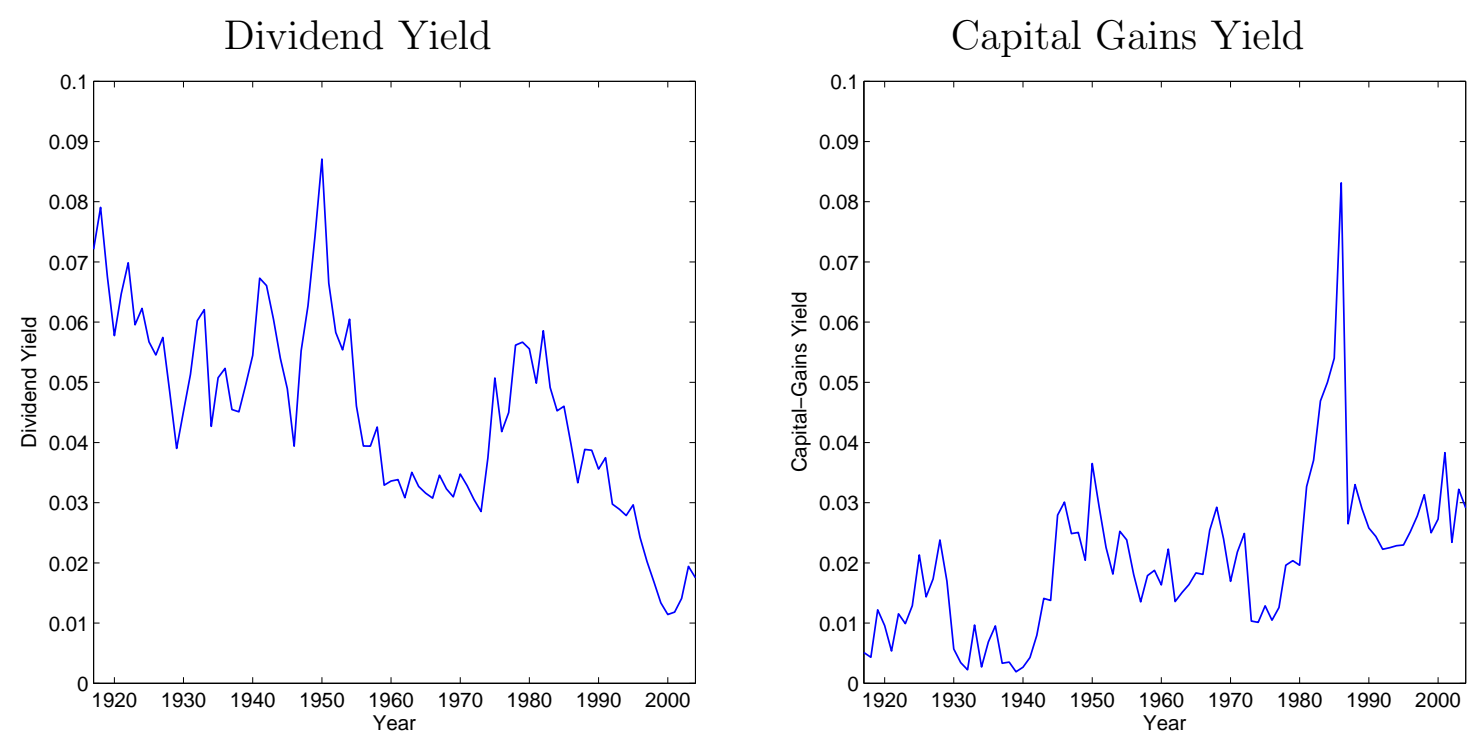
Figure 6: Effective Tax Rate on Stock Returns

This figure depicts the effective tax rates for all stocks. The more volatile curve corresponds to the effective tax rate with time-varying distribution weights, and the more stable curve corresponds to the effective tax rate with constant distribution weights.

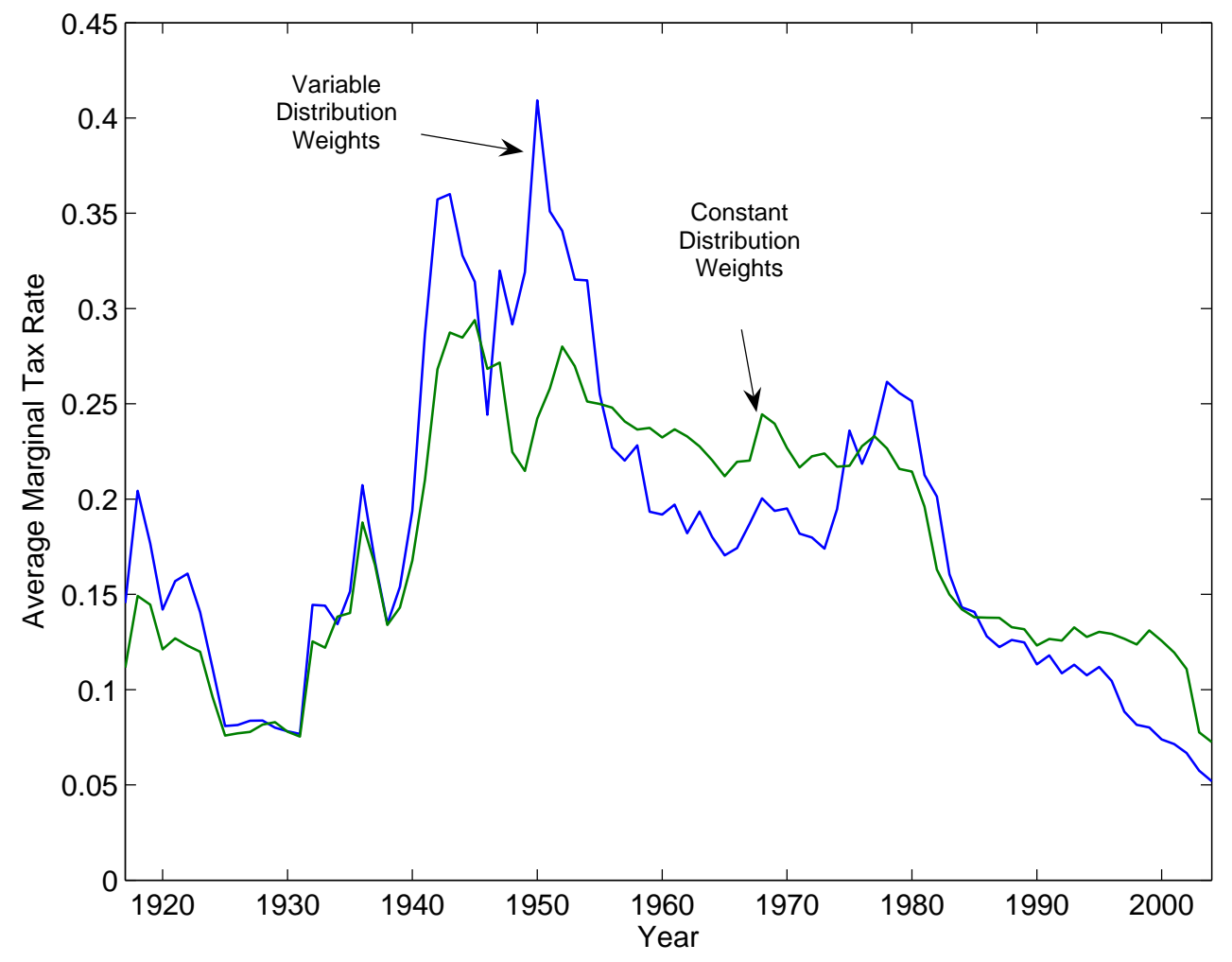


Figure 7: Asset Valuations

The price-earnings, the price-dividend, and Tobin's $q$ ratio are depicted over the period from 1917-2004.
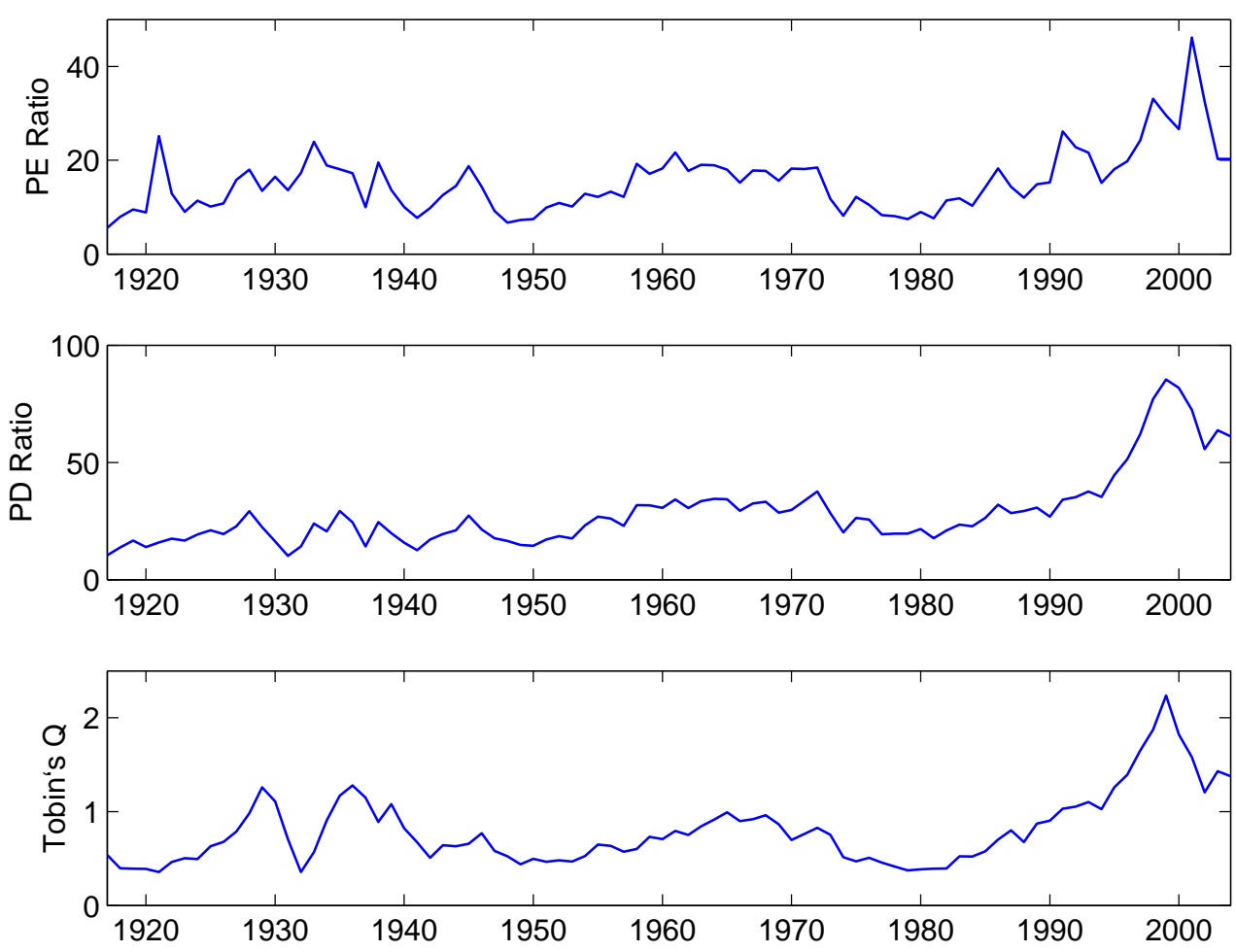
Table 1: Summary Statistics of Macroeconomic Variables This table summarizes the means and the standard deviations of various tax rates and macroeconomic variables between 1917-2004. The third column shows the correlation between the corresponding variable and the effective tax rate.

\begin{tabular}{lrrc}
\hline & Mean & Std. Dev. & Correlation \\
\hline Panel A: Tax Variables & & & \\
Effective Tax Rate with Constant Weights & 17.68 & 6.30 & 100 \\
Effective Tax Rate with Time-Varying Weights & 18.05 & 8.21 & $87.29^{* * *}$ \\
Average Marginal Tax on Dividends & 33.45 & 11.75 & $91.55^{* * *}$ \\
Average Marginal Tax on Capital Gains & 18.25 & 4.77 & $21.12^{*}$ \\
Income Tax Rate (Income of \$100,000) & 21.27 & 11.07 & $56.88^{* * *}$ \\
Income Tax Rate (Income of \$250,000) & 34.71 & 16.55 & $80.62^{* * *}$ \\
Income Tax Rate (Maximum Income) & 63.30 & 22.65 & $86.19^{* * *}$ \\
\hline Panel B: Macroeconomic Variables & & & \\
P-E Ratio & 15.46 & 7.19 & $-28.86^{* * *}$ \\
P-D Ratio & 28.52 & 15.52 & $-24.42^{* *}$ \\
Tobin's q & 0.80 & 0.38 & $-38.13^{* * *}$ \\
Nominal S\&P Composite Return & 11.86 & 19.02 & 5.61 \\
Inflation Rate & 3.36 & 5.28 & $29.08^{* * *}$ \\
Real Per Capita Growth Rate & 1.99 & 6.81 & 15.56 \\
Nominal Interest Rate & 4.73 & 3.33 & $-13.97^{* *}$ \\
Democrat President Indicator Variable & 50.00 & 50.29 & $28.60^{* * *}$ \\
War Year Indicator Variable & 21.59 & 41.38 & $48.45^{* * *}$ \\
Recession Year Indicator Variable & 39.77 & 49.22 & -8.21 \\
\hline
\end{tabular}


Table 2: Asset Valuations in Different Tax Regimes

This table summarizes the effective tax rate using constant distribution weights, the price-earnings ratio, the price-dividend ratio, and Tobin's $q$ ratio for different tax regimes in our sample. The table also includes the Spearman rank correlations and the corresponding p-values in parentheses. The significance levels are abbreviated with asterisks: One, two, and three asterisks denote significance at the 10, 5, and 1 percent level, respectively.

\begin{tabular}{|c|c|c|c|c|c|}
\hline & Time Period & Tax Rate & P-E Ratio & P-D Ratio & Tobin's $q$ \\
\hline 1 & $1917-1923$ & 12.81 & 11.29 & 14.97 & 0.43 \\
\hline 2 & 1924-1931 & 8.06 & 13.71 & 20.07 & 0.83 \\
\hline 3 & $1932-1935$ & 13.15 & 19.56 & 22.00 & 0.75 \\
\hline 4 & 1936-1939 & 15.75 & 15.11 & 20.73 & 1.10 \\
\hline 5 & $1940-1947$ & 25.65 & 12.12 & 19.04 & 0.66 \\
\hline 6 & 1948-1950 & 22.72 & 7.15 & 15.25 & 0.49 \\
\hline 7 & $1951-1963$ & 24.62 & 14.97 & 26.52 & 0.63 \\
\hline 8 & 1964-1968 & 22.35 & 17.53 & 32.79 & 0.94 \\
\hline 9 & 1969-1981 & 22.16 & 11.80 & 25.23 & 0.57 \\
\hline 10 & $1982-1986$ & 14.66 & 13.22 & 25.11 & 0.54 \\
\hline 11 & 1987-1992 & 12.99 & 17.57 & 30.78 & 0.89 \\
\hline 12 & 1993-1996 & 13.06 & 18.67 & 42.22 & 1.20 \\
\hline 13 & 1997-2000 & 12.77 & 28.40 & 76.61 & 1.90 \\
\hline 14 & $2001-2002$ & 11.62 & 39.33 & 64.08 & 1.39 \\
\hline 15 & 2003-2004 & 7.58 & 20.27 & 62.44 & 1.40 \\
\hline \multicolumn{3}{|c|}{$\begin{array}{l}\text { Spearman Rank Correlation } \\
\text { P-Value }\end{array}$} & $\begin{array}{r}-0.55^{* *} \\
(0.034)\end{array}$ & $\begin{array}{l}-0.39 \\
(0.148)\end{array}$ & $\begin{array}{r}-0.52^{* *} \\
(0.048)\end{array}$ \\
\hline
\end{tabular}


Table 3: Relationship Between Taxes and the Price-Earnings Ratio This table summarizes the coefficients of the following regression: $p_{t} / e_{t}=\alpha_{0}+$ $\alpha_{1} \tau_{t}^{\text {const }}+\alpha_{2} r f_{t}+\alpha_{3} \pi_{t}+\alpha_{4} g_{t}+\alpha_{5} d_{e m_{t}}+\alpha_{6} r e c_{t}+\alpha_{7} w r_{t}+\alpha_{8} t+\epsilon_{t}$, where $p_{t} / e_{t}$ is the price of the Standard \& Poor's Composite Index at the end of year $t$ divided by the earnings of the underlying stocks during year $t ; \tau_{t}^{\text {const }}$ is the effective tax rate using constant distribution weights; $r f_{t}$ is the risk-free interest rate; $\pi_{t}$ is the inflation rate; $g_{t}$ is the per-capita real growth rate of GDP; $d e m_{t}$ is an indicator variable for whether the president is a Democrat; $r e c_{t}$ is an indicator variable for whether the current year is a recession year according to NBER; war $r_{t}$ is an indicator variable for whether the current year is a war year; and $t$ is a linear time trend. The Newey-West standard errors are summarized in parentheses and use a four-year lag. The significance levels are abbreviated with asterisks: One, two, and three asterisks denote significance at the 10,5 , and 1 percent level, respectively.

\begin{tabular}{lcc}
\hline & Univariate & Multivariate \\
& Estimates & Estimates \\
\hline Effective Tax Rate & $-30.75^{*}$ & $-35.00^{* * *}$ \\
& $(17.22)$ & $(12.84)$ \\
Interest Rate & & $-71.74^{* * *}$ \\
& & $(22.75)$ \\
Inflation Rate & & $-32.38^{* * *}$ \\
& & $(11.85)$ \\
Growth Rate & & -11.74 \\
& & $(11.11)$ \\
Democrat & & 1.06 \\
& & $(1.51)$ \\
Recession & & 1.62 \\
& & $(2.00)$ \\
War & & 2.30 \\
& & $(1.62)$ \\
Time Trend & & $0.18^{* * *}$ \\
& & $(0.05)$ \\
Constant & $20.90^{* * *}$ & $17.01^{* * *}$ \\
& $(3.81)$ & $(2.33)$ \\
\hline Observations & 88 & 88 \\
$R^{2}$ & 0.08 & 0.49 \\
\hline
\end{tabular}


Table 4: Relationship Between Taxes and the Price-Earnings Ratio This table summarizes the coefficients of the following regression: $p_{t+k} / e_{t+k}=\alpha_{0}+$ $\alpha_{1} \tau_{t}^{\text {const }}+\alpha_{2} r f_{t}+\alpha_{3} \pi_{t}+\alpha_{4} g_{t}+\alpha_{5} d_{e m_{t}}+\alpha_{6} r e c_{t}+\alpha_{7} w a r_{t}+\alpha_{8} t+\epsilon_{t+k}$, where $p_{t+k} / e_{t+k}$ is the price of the Standard \& Poor's Composite Index at the end of year $t+k$ divided by the earnings of the underlying stocks during year $t+k$ with $k \in(0,1) ; \tau_{t}^{\text {const }}$ is the effective tax rate using constant distribution weights; $r f_{t}$ is the risk-free interest rate; $\pi_{t}$ is the inflation rate; $g_{t}$ is the per-capita real growth rate of GDP; dem $m_{t}$ is an indicator variable for whether the president is a Democrat; $r e c_{t}$ is an indicator variable for whether the current year is a recession year according to NBER; war $_{t}$ is an indicator variable for whether the current year is a war year; and $t$ is a linear time trend. The first column reports the regression results using this year's price-earnings ratio, while the second column reports the results using next year's price-earnings ratio and the explanatory variables in the current year. The Newey-West standard errors are summarized in parentheses and use a four-year lag. The significance levels are abbreviated with asterisks: One, two, and three asterisks denote significance at the 10,5 , and 1 percent level, respectively.

\begin{tabular}{lcc}
\hline & This Year's & Next Year's \\
& $\begin{array}{c}\text { Price-Earnings Ratio } \\
\left(p_{t} / e_{t}\right)\end{array}$ & $\begin{array}{c}\text { Price-Earnings Ratio } \\
\left(p_{t+1} / e_{t+1}\right)\end{array}$ \\
\hline Effective Tax Rate & $-35.00^{* * *}$ & $-41.50^{* * *}$ \\
Interest Rate & $(12.84)$ & $(15.32)$ \\
& $-71.74^{* * *}$ & -28.48 \\
Inflation Rate & $(22.75)$ & $(23.60)$ \\
& $-32.38^{* * *}$ & $-41.25^{* * *}$ \\
Growth Rate & $(11.85)$ & $(10.70)$ \\
& -11.74 & 4.70 \\
Democrat & $(11.11)$ & $(6.42)$ \\
& 1.06 & 3.05 \\
Recession & $(1.51)$ & $(2.22)$ \\
& 1.62 & $3.35^{* *}$ \\
War & $(2.00)$ & $(1.39)$ \\
& 2.30 & $2.83^{*}$ \\
Time Trend & $(1.62)$ & $(1.65)$ \\
& $0.18^{* * *}$ & $0.17^{* * *}$ \\
Constant & $(0.05)$ & $(0.04)$ \\
& $17.01^{* * *}$ & $14.48^{* * *}$ \\
\hline Observations & $(2.33)$ & $(2.37)$ \\
$R^{2}$ & 88 & 87 \\
& 0.49 & 0.45 \\
\hline
\end{tabular}


Table 5: Relationship Between Taxes and the Price-Earnings Ratio: Different Tax Rates

This table summarizes the coefficients of the following regression: $p_{t} / e_{t}=\alpha_{0}+\alpha_{1} \tau_{t}+$ $\alpha_{2} r f_{t}+\alpha_{3} \pi_{t}+\alpha_{4} g_{t}+\alpha_{5} d e m_{t}+\alpha_{6} r e c_{t}+\alpha_{7} w_{a r}+\alpha_{8} t+\epsilon_{t}$, where $p_{t} / e_{t}$ the price of the Standard \& Poor's Composite Index at the end of year $t$ divided by the earnings of the underlying stocks during year $t ; \tau_{t}$ is tax rate; $r f_{t}$ is the risk-free interest rate; $\pi_{t}$ is the inflation rate; $g_{t}$ is the per-capita real growth rate of GDP; $d e m_{t}$ is an indicator variable for whether the president is a Democrat; $r e c_{t}$ is an indicator variable for whether the current year is a recession year according to NBER; war $_{t}$ is an indicator variable for whether the current year is a war year; and $t$ is a linear time trend. The different columns represent coefficient estimates using different tax rates. The Newey-West standard errors are summarized in parentheses and use a four-year lag. The significance levels are abbreviated with asterisks: One, two, and three asterisks denote significance at the 10,5 , and 1 percent level, respectively.

\begin{tabular}{lcccccc}
\hline & \multicolumn{3}{c}{ Effective Tax Rates } & \multicolumn{3}{c}{ Statutory Tax Rates } \\
& Constant & Varying & Div- & $\$ 100,000$ & $\$ 250,000$ & Maximum \\
& Weights & Weights & idends & & & \\
\hline Tax Rate & $-35.00^{* * *}$ & $-42.70^{* * *}$ & $-19.62^{* * *}$ & $-25.38^{* *}$ & $-14.57^{* * *}$ & $-6.48^{* *}$ \\
& $(12.84)$ & $(8.85)$ & $(6.87)$ & $(10.22)$ & $(5.28)$ & $(3.23)$ \\
Interest Rate & $-71.74^{* * *}$ & $-75.78^{* * *}$ & $-64.02^{* * *}$ & $-52.08^{* *}$ & $-55.32^{* *}$ & $-66.94^{* * *}$ \\
& $(22.75)$ & $(19.02)$ & $(21.40)$ & $(22.16)$ & $(21.36)$ & $(23.83)$ \\
Inflation Rate & $-32.38^{* * *}$ & $-26.04^{* *}$ & $-32.00^{* * *}$ & $-31.70^{* *}$ & $-31.56^{* *}$ & $-36.63^{* * *}$ \\
& $(11.85)$ & $(10.77)$ & $(11.99)$ & $(13.34)$ & $(12.45)$ & $(12.31)$ \\
Growth Rate & -11.74 & -11.85 & -11.24 & -15.45 & -13.82 & -10.82 \\
& $(11.11)$ & $(10.00)$ & $(11.09)$ & $(11.20)$ & $(11.09)$ & $(11.50)$ \\
Democrat & 1.06 & 1.57 & 1.20 & 0.74 & 0.75 & 1.29 \\
& $(1.51)$ & $(1.24)$ & $(1.47)$ & $(1.47)$ & $(1.49)$ & $(1.55)$ \\
Recession & 1.62 & 1.94 & 1.51 & 1.02 & 1.22 & 1.58 \\
& $(2.00)$ & $(1.87)$ & $(1.97)$ & $(1.96)$ & $(1.99)$ & $(2.02)$ \\
War & 2.30 & $3.33^{* * *}$ & 1.98 & 1.73 & 2.05 & 0.98 \\
& $(1.62)$ & $(1.16)$ & $(1.48)$ & $(1.35)$ & $(1.50)$ & $(1.63)$ \\
Time Trend & $0.18^{* * *}$ & $0.15^{* * *}$ & $0.20^{* * *}$ & $0.24^{* * *}$ & $0.21^{* * *}$ & $0.15^{* * *}$ \\
& $(0.05)$ & $(0.04)$ & $(0.05)$ & $(0.06)$ & $(0.05)$ & $(0.05)$ \\
Constant & $17.01^{* * *}$ & $19.02^{* * *}$ & $15.83^{* * *}$ & $13.11^{* * *}$ & $13.93^{* * *}$ & $16.02^{* * *}$ \\
& $(2.33)$ & $(2.04)$ & $(2.28)$ & $(2.31)$ & $(2.23)$ & $(2.49)$ \\
\hline Observations & 88 & 88 & 88 & 88 & 88 & 88 \\
$R^{2}$ & 0.49 & 0.59 & 0.49 & 0.48 & 0.49 & 0.45 \\
\hline
\end{tabular}


Table 6: Relationship Between Taxes and Asset Valuation: Various Valuation Ratios This table summarizes the coefficients of the following regression: $v_{a} l_{t}=\alpha_{0}+$ $\alpha_{1} \tau_{t}^{\text {const }}+\alpha_{2} r f_{t}+\alpha_{3} \pi_{t}+\alpha_{4} g_{t}+\alpha_{5} d_{e} m_{t}+\alpha_{6} r e c_{t}+\alpha_{7} w_{a r}+\alpha_{8} t+\epsilon_{t}$, where $v a l_{t}$ is the valuation ratio at the end of year $t$; $\tau_{t}^{\text {const }}$ is the effective tax rate using constant distribution weights; $r f_{t}$ is the risk-free interest rate; $\pi_{t}$ is the inflation rate; $g_{t}$ is the per-capita real growth rate of GDP; $d e m_{t}$ is an indicator variable for whether the president is a Democrat; $r e c_{t}$ is an indicator variable for whether the current year is a recession year according to NBER; war $r_{t}$ is an indicator variable for whether the current year is a war year; and $t$ is a linear time trend. The Newey-West standard errors are summarized in parentheses and use a four-year lag. The results using various valuation ratios are summarized in the columns: (1) price earnings ratio; (2) price earnings ratio where the earnings are defined as the average earnings over the previous five years; (3) price earnings ratio where the earnings are defined as the average earnings over the previous ten years; (4) price dividend ratio; (5) Tobin's $q$ ratio. The significance levels are abbreviated with asterisks: One, two, and three asterisks denote significance at the 10, 5, and 1 percent level, respectively.

\begin{tabular}{lccccc}
\hline & \multicolumn{5}{c}{ Equity Valuation Ratios } \\
& PE Ratio & PE5 Ratio & PE10 Ratio & PD Ratio & Tobin's $q$ \\
\hline Effective Tax Rate & $-35.00^{* * *}$ & $-29.94^{* * *}$ & $-33.42^{* *}$ & $-82.63^{* * *}$ & $-3.08^{* * *}$ \\
& $(12.84)$ & $(11.03)$ & $(15.43)$ & $(30.27)$ & $(0.61)$ \\
Interest Rate & $-71.74^{* * *}$ & $-63.48^{* * *}$ & $-54.09^{*}$ & $-132.21^{* * *}$ & $-3.84^{* * *}$ \\
& $(22.75)$ & $(20.50)$ & $(27.51)$ & $(39.21)$ & $(1.08)$ \\
Inflation Rate & $-32.38^{* * *}$ & $-21.44^{*}$ & $-24.60^{*}$ & -23.48 & -1.18 \\
& $(11.85)$ & $(11.70)$ & $(14.31)$ & $(21.32)$ & $(0.73)$ \\
Growth Rate & -11.74 & 10.20 & 2.84 & 0.18 & 0.75 \\
& $(11.11)$ & $(9.92)$ & $(9.28)$ & $(16.27)$ & $(0.50)$ \\
Democrat & 1.06 & 2.26 & 3.03 & 4.09 & $0.21^{* *}$ \\
& $(1.51)$ & $(1.66)$ & $(2.40)$ & $(4.35)$ & $(0.11)$ \\
Recession & 1.62 & -0.12 & 0.10 & 1.51 & 0.07 \\
& $(2.00)$ & $(1.20)$ & $(1.35)$ & $(2.65)$ & $(0.08)$ \\
War & 2.30 & 0.11 & 2.17 & 3.03 & 0.07 \\
& $(1.62)$ & $(1.90)$ & $(1.71)$ & $(2.77)$ & $(0.09)$ \\
Time Trend & $0.18^{* * *}$ & $0.19^{* * *}$ & $0.24^{* * *}$ & $0.53^{* * *}$ & $0.01^{* * *}$ \\
& $(0.05)$ & $(0.03)$ & $(0.05)$ & $(0.11)$ & $(0.00)$ \\
Constant & $17.01^{* * *}$ & $15.84^{* * *}$ & $14.68^{* * *}$ & $24.04^{* * *}$ & $0.95^{* * *}$ \\
& $(2.33)$ & $(2.52)$ & $(3.50)$ & $(4.52)$ & $(0.12)$ \\
\hline Observations & 88 & 88 & 88 & 88 & 88 \\
$R^{2}$ & 0.49 & 0.58 & 0.59 & 0.65 & 0.62 \\
\hline
\end{tabular}


Table 7: Relationship Between Taxes and the Price-Earnings Ratio: Different Variable Transformations

This table summarizes the coefficients of the following regression: $v_{a l}=\alpha_{0}+\alpha_{1} \operatorname{tax}_{t}+$ $\alpha_{2} r f_{t}+\alpha_{3} \pi_{t}+\alpha_{4} g_{t}+\alpha_{5}$ dem $_{t}+\alpha_{6} r e c_{t}+\alpha_{7}$ war $_{t}+\alpha_{8} t+\epsilon_{t}$, where val $_{t}$ is either the price-earnings ratio at the end of year $t$ (columns 1 and 2) or the logarithm of the price-earnings ratio at the end of year $t$ (columns 3 and 4 ); tax $x_{t}$ is either $\tau_{t}^{\text {const }}$ (columns 1 and 3$)$ or $\ln \left(1-\tau_{t}^{\text {const }}\right)$ (columns 2 and 4$) ; r f_{t}$ is the risk-free interest rate; $\pi_{t}$ is the inflation rate; $g_{t}$ is the per-capita real growth rate of GDP; dem $_{t}$ is an indicator variable for whether the president is a Democrat; $r e c_{t}$ is an indicator variable for whether the current year is a recession year according to NBER; war is an indicator variable for whether the current year is a war year; and $t$ is a linear time trend. The Newey-West standard errors are summarized in parentheses and use a four-year lag. The significance levels are abbreviated with asterisks: One, two, and three asterisks denote significance at the 10,5, and 1 percent level, respectively.

\begin{tabular}{|c|c|c|c|c|}
\hline \multirow{2}{*}{ Effective Tax Rate } & \multicolumn{2}{|c|}{$\begin{array}{c}\text { Raw } \\
\text { Price-Earnings Ratio }\end{array}$} & \multicolumn{2}{|c|}{$\begin{array}{c}\text { Logarithm of } \\
\text { Price-Earnings Ratio }\end{array}$} \\
\hline & $\begin{array}{l}-35.00^{* * *} \\
(12.84)\end{array}$ & & $\begin{array}{c}-1.71^{* *} \\
(0.77)\end{array}$ & \\
\hline Log of (1 - Effective Tax Rate) & & $\begin{array}{l}28.96^{* * *} \\
(10.48)\end{array}$ & & $\begin{array}{l}1.41^{* *} \\
(0.63)\end{array}$ \\
\hline Interest Rate & $\begin{array}{l}-71.74^{* * *} \\
(22.75)\end{array}$ & $\begin{array}{l}-72.88^{* * *} \\
(22.77)\end{array}$ & $\begin{array}{c}-4.07^{* * *} \\
(1.38)\end{array}$ & $\begin{array}{c}-4.13^{* *} \\
(1.38)\end{array}$ \\
\hline Inflation Rate & $\begin{array}{l}-32.38^{* * *} \\
(11.85)\end{array}$ & $\begin{array}{l}-32.26^{* * *} \\
(11.80)\end{array}$ & $\begin{array}{l}-2.70^{* * *} \\
(0.82)\end{array}$ & $\begin{array}{c}-2.69^{* *} \\
(0.81)\end{array}$ \\
\hline Growth Rate & $\begin{array}{r}-11.74 \\
(11.11)\end{array}$ & $\begin{array}{r}-12.05 \\
(11.10)\end{array}$ & $\begin{array}{r}-0.80 \\
(0.72)\end{array}$ & $\begin{array}{c}-0.82 \\
(0.72)\end{array}$ \\
\hline Democrat & $\begin{array}{l}1.06 \\
(1.51)\end{array}$ & $\begin{array}{c}1.02 \\
(1.51)\end{array}$ & $\begin{array}{c}0.02 \\
(0.10)\end{array}$ & $\begin{array}{c}0.02 \\
(0.10)\end{array}$ \\
\hline Recession & $\begin{array}{l}1.62 \\
(2.00)\end{array}$ & $\begin{array}{l}1.60 \\
(2.00)\end{array}$ & $\begin{array}{c}0.02 \\
(0.11)\end{array}$ & $\begin{array}{c}0.02 \\
(0.11)\end{array}$ \\
\hline War & $\begin{array}{c}2.30 \\
(1.62)\end{array}$ & $\begin{array}{c}2.36 \\
(1.60)\end{array}$ & $\begin{array}{c}0.13 \\
(0.12)\end{array}$ & $\begin{array}{c}0.14 \\
(0.12)\end{array}$ \\
\hline Time Trend & $\begin{array}{l}0.18^{* * *} \\
(0.05)\end{array}$ & $\begin{array}{l}0.18^{* * *} \\
(0.05)\end{array}$ & $\begin{array}{l}0.01^{* * *} \\
(0.00)\end{array}$ & $\begin{array}{l}0.01^{* * *} \\
(0.00)\end{array}$ \\
\hline Constant & $\begin{array}{l}17.01^{* * *} \\
(2.33)\end{array}$ & $\begin{array}{l}16.62^{* * *} \\
(2.24)\end{array}$ & $\begin{array}{l}2.79^{* * *} \\
(0.15) \\
\end{array}$ & $\begin{array}{l}2.77^{* * *} \\
(0.14)\end{array}$ \\
\hline $\begin{array}{l}\text { Observations } \\
R^{2}\end{array}$ & $\begin{array}{l}88 \\
0.49\end{array}$ & $\begin{array}{c}88 \\
0.49\end{array}$ & $\begin{array}{c}88 \\
0.51\end{array}$ & $\begin{array}{l}88 \\
0.48\end{array}$ \\
\hline
\end{tabular}


Table 8: Asset Returns and Taxes

This table summarizes the coefficients of the following OLS regression: $r_{t+k}=\alpha_{0}+$ $\alpha_{1} \tau_{t}+\alpha_{2} r f_{t}+\alpha_{3} \pi_{t}+\alpha_{4} g_{t}+\alpha_{5}$ dem $_{t}+\alpha_{6} r e c_{t}+\alpha_{7} w_{a r}+\alpha_{8} t+\epsilon_{t+k}$, where $r_{t+k}$ is the nominal return on the $\mathrm{S} \& \mathrm{P}$ Composite Index during year $t+k$ with $k \in(0,1)$; $\tau_{t}$ is the aggregate effective tax rate using time-varying distribution weights; $r f_{t}$ is the risk-free interest rate; $\pi_{t}$ is the inflation rate; $g_{t}$ is the per-capita real growth rate of GDP; dem $m_{t}$ is an indicator variable for whether the president is a Democrat; $r e c_{t}$ is an indicator variable for whether the current year is a recession year according to NBER; war $_{t}$ is an indicator variable for whether the current year is a war year; and $t$ is a linear time trend. The first column uses the return in the current year, and the second column uses the return in the subsequent year as the dependent variable. The Newey-West standard errors are summarized in parentheses and use a four-year lag. The significance levels are abbreviated with asterisks: One, two, and three asterisks denote significance at the 10,5 , and 1 percent level, respectively.

\begin{tabular}{lcc}
\hline & $\begin{array}{c}\text { This Year's Return } \\
\left(r_{t}\right)\end{array}$ & $\begin{array}{c}\text { Next Year's Return } \\
\left(r_{t+1}\right)\end{array}$ \\
\hline Tax Rate & $0.61^{* *}$ & $0.50^{*}$ \\
& $(0.24)$ & $(0.29)$ \\
Interest Rate & 0.27 & 0.65 \\
& $(0.58)$ & $(0.42)$ \\
Inflation Rate & -0.48 & -0.32 \\
& $(0.55)$ & $(0.31)$ \\
Growth Rate & 0.14 & 0.18 \\
& $(0.49)$ & $(0.27)$ \\
Democrat & 0.00 & -0.02 \\
& $(0.05)$ & $(0.04)$ \\
Recession & -0.05 & 0.01 \\
& $(0.06)$ & $(0.06)$ \\
War & -0.06 & -0.02 \\
& $(0.05)$ & $(0.05)$ \\
Time Trend & 0.00 & 0.00 \\
& $(0.00)$ & $(0.00)$ \\
Constant & 0.03 & 0.01 \\
& $(0.12)$ & $(0.09)$ \\
\hline Observations & 88 & 87 \\
$R^{2}$ & 0.07 & 0.04 \\
\hline
\end{tabular}

